\title{
As múltiplas faces de Valério Vieira
}

The multiple faces of Valério Vieira

https://doi.org/10.1590/1982-02672021v29e5

\section{ÉRICO MONTEIRO ELIAS'}

https:/ / orcid.org/0000-0003-2226-2127

Universidade Estadual de Campinas / Campinas, SP, Brasil

RESUMO: Este artigo propõe uma análise da obra de Valério Vieira (1862-1941) dividida em cinco partes. Na primeira parte, resgata os processos criativos envolvidos na concepção de Os trinta Valérios (c. 1900) e do Segundo panorama de São Paulo (1922), enquadrando as duas obras em seus contextos históricos. A análise permite delinear o perfil de um autor mais vinculado a práticas da fotografia oitocentista do que alinhadas a propostas do modernismo, sem deixar de sublinhar sua originalidade. Nas quatro partes seguintes, aborda as relações estabelecidas entre a obra de Valério Vieira e outros campos da arte: cinema, teatro e música, em diálogos reais ou imaginários travados com artistas como Georges Meliès, Leopoldo Fregoli, Almirante e Pixinguinha.

PALAVRAS-CHAVE: Valério Vieira. Fotografia. História da Fotografia. Fotomontagem. Autorretrato.

ABSTRACT: This article aims to analyse the work of Valerio Vieira (1862-1941) in five parts. The first part revisits the creative processes entailed in the making of Os Trinta Valérios (c. 1900) and Segundo panorama de São Paulo (1922) as we look at both works in connection with their historical context. The present analysis sheds lights on an author whose work is more aligned with the practices of nineteenth-century photograph rather than the proposals of modernism, while highlighting the artist's originality. In the four subsequent parts, we approach the relations between Valerio Vieira's work and other fields of art: cinema, theatre, and music through real or imaginary interchanges with artists like Georges Melies, Leopoldo Fregoli, Almirante and Pixinguinha.

KEYWORDS: Valerio Vieira. Photography. History of Photography. Photomontage. Self-portrait.

\begin{abstract}
1. Possui graduação em Jornalismo pela Universidade Estadual Paulista. Cursou graduação em Fotografia por dois anos e meio na Faculdade Senac. É mestre pelo Instituto de Artes da Universidade Estadual de Campinas (Unicamp). Tem experiência nas áreas de Comunicação e Artes, com ênfase em Fotografia e Cinema.E-mail: <erico@ericoelias.com>.
\end{abstract}


2. Optamos por utilizar ora "Valério Vieira", para designar o indivíduo, ora apenas "Valerio", para designar o personagem assumido pelo fotógrafo. É assim que ele se apresentava aos clientes, apenas como "Valerio", elidindo o sobrenome e o acento agudo no nome.

3. Kossoy (1999; 2001; 2007).
Valério Vieira (1862-1941) é um personagem bastante conhecido na história da fotografia brasileira, sobre o qual muito ainda resta a ser pesquisado. Ele é autor de Os trinta Valérios (c. 190 1), obra cuja originalidade permite situá-lo entre os mais importantes fotógrafos da passagem do século XIX ao XX (Figura 1). No interior de uma cena minuciosamente construída, Valerio assume todos os personagens de uma animada apresentação musical. Atuando como fotógrafo e como modelo, como autor e como ator, ele se apresenta a seu público, seus clientes em potencial, em uma soma de três artifícios, que o posicionam abertamente no polo da manipulação e da ficção: a mise-en-scène, o autorretrato e a fotomontagem. O que marca a originalidade de Valerio é assumir-se em um tal agenciamento de formas que transfigura a fotografia em ferramenta para a criação de um mundo mágico. Em seu trabalho está presente a dupla dimensão da fotografia, sua ambiguidade fundamental entre realismo e manipulação, como documento de uma época e como expressão de uma autoria, objetividade e subjetividade inextrincáveis, assim como explicitado por Boris Kossoy ao longo de sua trilogia acerca das realidades e ficções na trama fotográfica. ${ }^{3}$

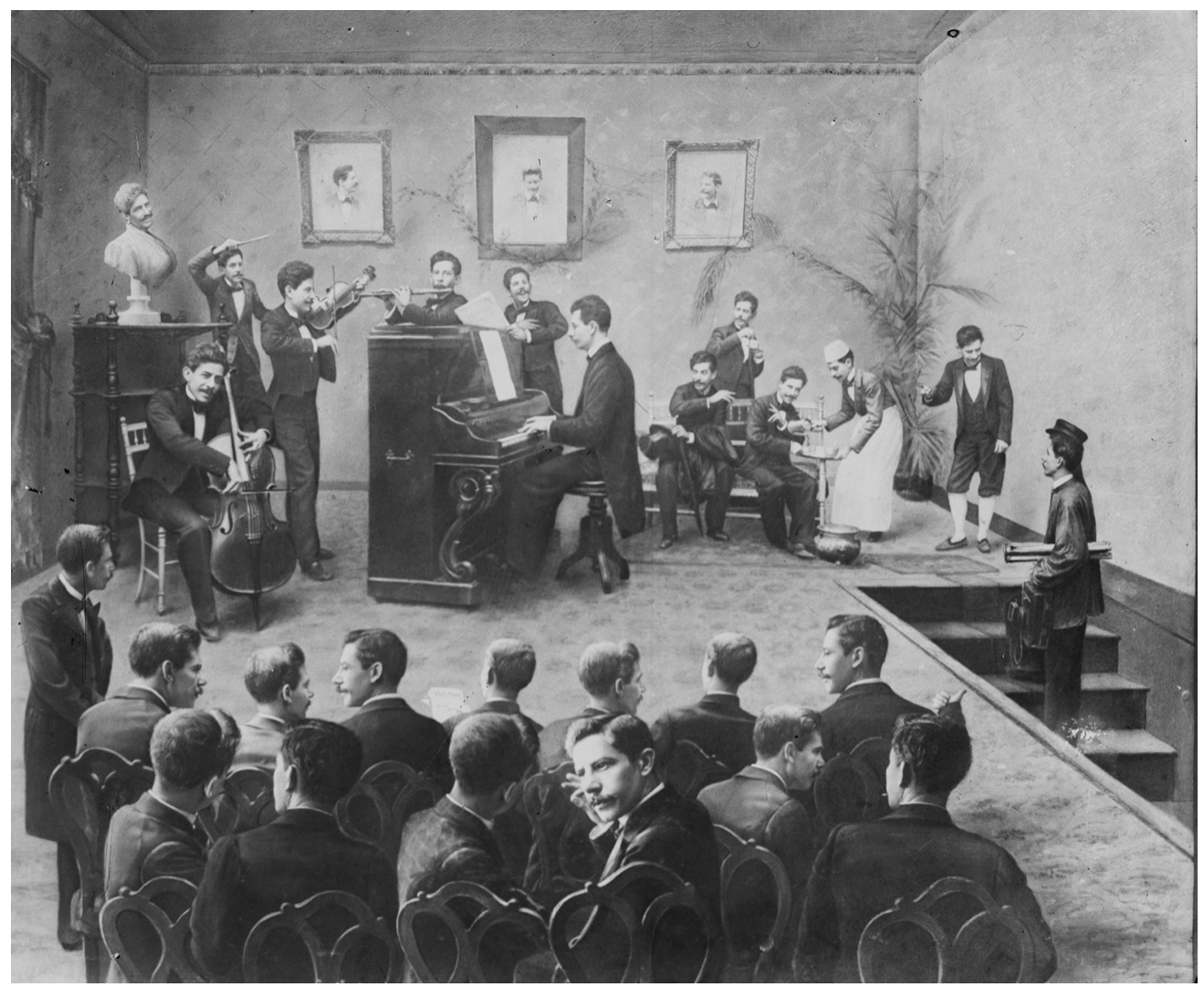

Figura 1 - Os trinta Valérios (c. 1901), Valério Vieira. Fonte: Acervo Museu Paulista da Universidade de São Paulo. Créditos fotográficos da reprodução: Hélio Nobre e José Rosael. 
Quando nos acercarmos de Valério Vieira, descobrimos também uma outra face dessa trama. Uma vez compreendido em seu momento histórico, Valerio passa a fazer sentido diante de um quadro de referências que está muito mais relacionado aos parâmetros da fotografia oitocentista do que de valores posteriormente ligados à proposta modernista. Entendemos que Os trinta Valérios não pode figurar como uma espécie de modernismo avant la lettre, embora haja na obra muitos aspectos próprios da modernidade. Tanto é que, alguns anos após realizar Os trinta Valérios, Valério Vieira encontra-se, em 1922, ano em que eclode a Semana de Arte Moderna, completamente enfronhado em um projeto de proporções gigantescas e estreitamente vinculado a uma proposta de propaganda oficial, o Segundo panorama de São Paulo. Tentaremos desenvolver essas contradições ao longo do primeiro item deste artigo. Uma vez mais, é a obra de Boris Kossoy que nos permite colocar em perspectiva crítica a atividade de Valerio, ao cotejá-la com a de Guilherme Gaensly (1843-1928). Em Realidades e ficções na trama fotográfica, Kossoy questiona a pretensão de neutralidade da representação oficial que Gaensly deu à São Paulo do início do século XX, metrópole emergente, fruto da prosperidade das oligarquias cafeeiras que logo se transmutariam em industriais. A "europeização" de que fala Kossoy está em profunda dissonância com a proposta modernista, expressa no Manifesto Pau-Brasil: deglutir o colonizador para criar uma arte autêntica. ${ }^{4}$

Essa dupla dimensão de Valerio, como artista experimental e inovador e, ao mesmo tempo, como intérprete alinhado à construção de uma visão oficial, pode derivar, em grande parte, da própria atividade profissional do personagem, em um momento em que a fotografia se transformou em febre comercial, em meio de construção de personalidades públicas, e ainda estava longe de ser plenamente aceita como "arte", não havendo forjado o seu público. Também buscamos explorar a originalidade de Valerio em seu contexto histórico e demonstramos como sua obra flerta de maneira transversal com outros campos: o cinema, o teatro e a música.

\section{FOTOGRAFIA, CIDADE, ESPETÁCULO}

Uma reportagem publicada no volume XXVI de The Strand Magazine, em 1903, apresenta ao público de língua inglesa a extraordinária trucagem fotográfica do Señor Valerio Vieira (sic). Publicada na Inglaterra e nos Estados Unidos entre 1891 e 1950, The Strand Magazine reunia temáticas diversas, além de novelas fantásticas em fascículos, de autores como Arthur Conan Doyle, E. Nesbitt, H. G. Wells e Hélène Vacaresco. ${ }^{5}$ A reportagem sobre o fotógrafo brasileiro está
4. Kossoy (1999, p. 69-70).

5. Os autores mencionados estão publicados no mesmo volume que traz o artigo sobre Valério Vieira. Dentre outros colaboradores da longeva revista estiveram Grant Allen, Margery Allingham, J. E. Preston Muddock, E. C. Bentley, Agatha Christie, Mary Angela Dickens, C. B. Fry, Walter Goodman, W. W. Jacobs, Rudyard Kipling, Arthur Morrison, Dorothy L. Sayers, Georges Simenon, Edgar Wallace, Max Beerbohm, P. G. Wodehouse, Dornford Yates e Winston Churchill. 
6. The Strand Magazine fazia uso intenso de imagens, sobretudo imagens fotográficas. Grande parte do repertório das seções "Some Wonders from the West" $\mathrm{e}$ "Curiosities" é ilustrada por fotomontagens ou fotografias ligadas a casos fantásticos ou exóticos, que tiram efeitos persuasivos do "realismo" fotográfico. Sobre as revistas ilustradas e seu acervo de trucagens fotográficas, cf. Chéroux (2015, p. 82-88).

7. Todos os textos originalmente em outra língua foram traduzidos ao português pelo autor do artigo.

8. The Strand Magazine, v. 26, p. $217,1903$.

9. Ricardo Mendes recolhe no documento "A Industria no Estado de São Paulo em 1901", de autoria de Antonio Francisco Bandeira Jr., informações sobre a invenção de Valério Vieira de um "cartão buquê". Embora seja realizado com múltiplos retratos, a descrição não parece coincidir com a montagem dos autorretratos em buquê. De qualquer maneira, trata-se de uma referência fundamental ao processo criativo de Valério e sua bem sucedida busca de inserção comercial por meio da invenção de novas técnicas e procedimentos ligados à manipulação fotográfica. "O 'Grande Estabelecimento Photographico', como o denomina Antonio Bandeira (1901), trabalha com os processos usuais na virada do século. Além da platinotipia, das imagens a óleo e aquarela, Valerio oferece ainda 'Photographia em alto relevo' e seus 'Retratos bouquets'. 'O seu processo de cartão bouquet, reproduzindo a mesma pessoa sete vezes, em sete posições diversas, com sete diversos vestuarios formando a mesma pessoa um grupo de sete figuras, é inteiramente original; como é inteiramente novo seu De- publicada sob a rubrica de "maravilhas do ocidente". ${ }^{\circ}$ Em suas primeiras linhas, situa o feito de Valerio no contexło da época?

Um dos truques favoritos de todo fotógrafo engenhoso é a multiplicação do retrato de uma pessoa em uma única fotografia. [...] Restou, no entanto, a um fotógrafo sul-americano, Señor Valerio Vieira, de São Paulo, Brasil, a tarefa de levar essa ilusão ao mais impressionante grau. ${ }^{8}$

A revista realça a excepcionalidade de Os trinta Valérios, em sua forma espontânea e criativa de empregar a trucagem fotográfica de maneira a obter uma formidável ilusão. Para definir o que o texto chama de "music picture", a melhor palavra a se empregar talvez seja o verbo em inglês "to play", que tem múltiplas possibilidades de tradução para o português, tais como jogar, brincar, tocar um instrumento musical, representar um papel, folgar ou gracejar. Todas essas dimensões estão presentes em Os trinta Valérios, o que faz com que a obra desperte inestimável interesse estético. Em um momento em que a visualidade salta ao primeiro plano dentre os espetáculos que entretêm um público ávido por novidades, Valerio convida os espectadores a jogar, descobrindo as múltiplas facetas do fotógrafo que se desdobram em cada corpo presente na cena. Ele brinca com a imaginação, partindo de uma mídia extremamente "realista" em seus traços, a fotografia, para obter um efeito ficcional. Ele representa um ato teatral por meio da música, ałuando como conjunto musical e como plateia, como serviçal e cliente, como espectador e fotógrafo. Faz com que uma mídia silenciosa reverbere sonoridades inesperadas na mente de quem observa. Enfim, ele torna mais leve o espírito de quem contempla, por meio de um gracejo escandido na expressão dos trinta personagens que interagem alegremente no descontraído sarau.

As peripécias do Señor Valerio apresentadas ao público da revista The Strand não terminam aí. Sua presença de espírito se demonstra faceira em outras duas imagens reproduzidas no mesmo artigo. Em uma delas, ele exibe seu rosto no centro das flores de um grande buquê (Figura 2). ${ }^{9} \mathrm{O}$ autor do artigo compara o truque, em seu engenho e requinte, com a rainha da ópera cômica inglesa "Iolanthe" (1882), com música de Arthur Sullivan e libreto de W. S. Gilbert, que fez sucesso na era vitoriana. $\bigcirc$ truque é definido como "efeito impressionante", contendo nada menos que quarenta reproduções do rosto de Valerio - "sem dúvida, a mais estranha elaboração que já passou pela cabeça de um fotógrafo", segundo as palavras da própria revista. Na outra imagem, Valerio se exibe em 13 expressões faciais, "expressando todas as emoções às quais a natureza humana pode estar sujeita" (Figura 3). 


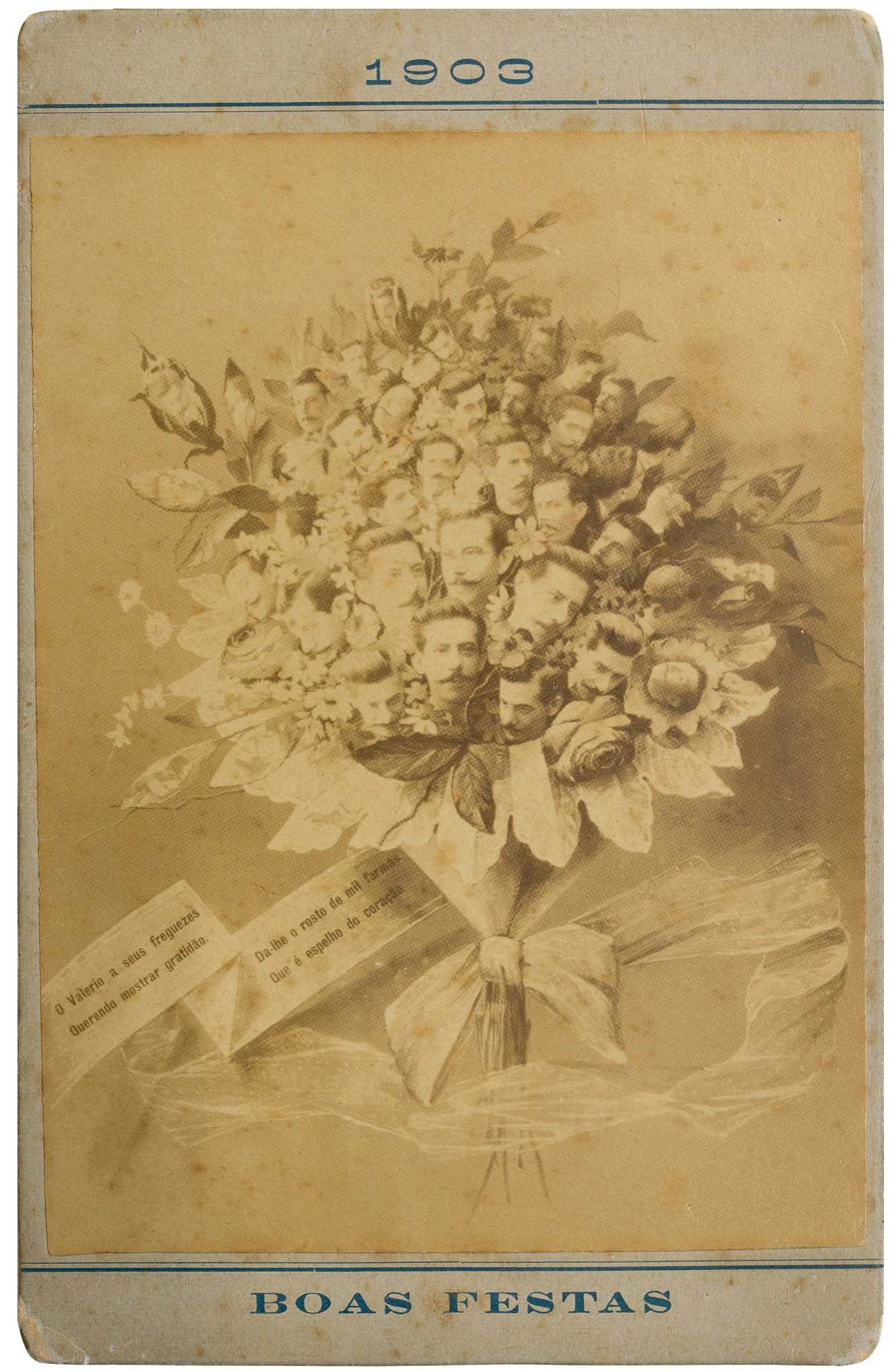

gradador Valerio, o qual consta de um pequeno apparelho que se adapta a qualquer machina, sendo a sua principal qualidade, a de abreviar oito procedimentos dando mais realce á photographia, sahindo a chapa da machina quasi concluinda'." Mendes (2006, p. 3).

Figura 2 - Boas Festas, fotomontagem em formato de buquê (1903), Valério Vieira. Fonte: Acervo Museu Paulista da Universidade de São Paulo. Créditos fotográficos da reprodução: Hélio Nobre e José Rosael. 
10. The Strand Magazine (v. 26, p. 218, 1903)

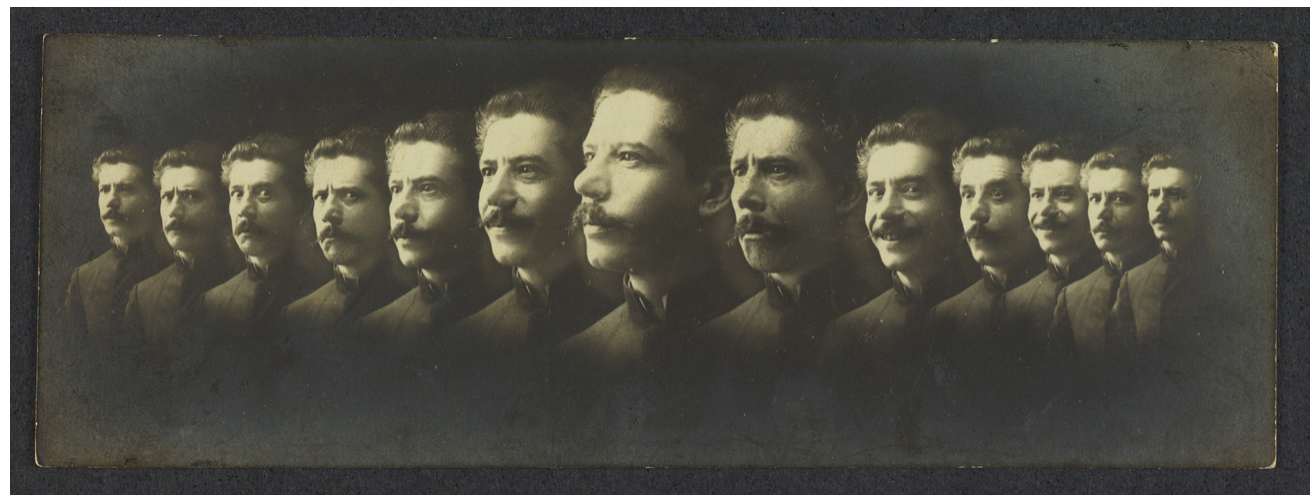

Figura 3 - Expressões Faciais em Múltipla Exposição: autorretrato (c. 1903), Valério Vieira. Fonte: Acervo Biblioteca Nacional.

A composição respeita uma evolução na escala que vai dos dois rostos menores, presentes nos cantos da imagem, até o rosto maior, que está centralizado. Valerio se lança em uma encenação das emoções, assim como Oscar G. Rejlander (1813-1875), fotógrafo oitocentista também conhecido por suas fotomontagens, havia feito sob encomenda de Charles Darwin, para o livro The Expression of the Emotions in Man and Animals, publicado originalmente em 1872. Embora o "experimento" conte com expressões de tristeza, sua realização deve ter sido motivada por significativa dose de bom humor.

$\bigcirc$ artigo da revista The Strand demonstra a dimensão que Valério Vieira conseguiu obter com seu trabalho à época. Ele circulou em uma popular e abrangente revista inglesa antes mesmo de ganhar a medalha de prata na Lovisiana Purchase Exposition, em 1904, com Os trinta Valérios. $\bigcirc$ autor do texto, não identificado, exalta a qualidade na execução de Valerio, que obtinha enorme sucesso em competições internacionais, levando prêmio após prêmio, sem que ninguém tivesse coragem de competir seriamente com ele no campo da multiplicação fotográfica.

Essas imagens são realmente "compósitas". Cada uma das cabeças e das figuras foi tomada separadamente e ampliações foram realizadas. As fotos foram então cuidadosamente cortadas e coladas em uma folha, que no final foi refotografada. $\bigcirc$ retoque de enorme habilidade é empregado em todo o trabalho do artista. Em nenhum dos casos o olho consegue detectar a linha de junção das imagens unidas para formar o conjunto. Esse é mesmo o segredo de seu enorme sucesso, que parece simples de fazer, mas que o fotógrafo habitual descobre ser muito difícil no momento em que tenta "compor". ${ }^{10}$

artigo na revista The Strand é relevante ainda por trazer uma longa citação de Valério Vieira. Segundo ele, não é de se estranhar seu sucesso na 
fotografia, já que o interesse pela arte e a técnica fołográficas vêm desde a infância. "Desde que estava maduro o suficiente para ter alguma ideia da real arte fotográfica, eu entendi que ela não consiste meramente em belas imagens e bons retratos", conta Valerio, sem esconder sua vontade de arte. Para além de uma brincadeira, portanto, sua intenção ao criar tais inovadoras fusões de autorretrato, mise-en-scène e fotomontagem é eminentemente estética. "O que tento obter é o extraordinário apresentado de forma artística", explicita.

Presentes no acervo do Museu Paulista, encontram-se o buquê e as treze expressões faciais, montados na forma de cartão de votos de boas festas. Ambos estão datados do mesmo ano em que foi publicado o artigo na The Strand Magazine, 1903. Os cartões revelam que, para além da intenção artística, Valerio fazia uso de suas criações para cativar a clientela. Na fita que enfeixa o buquê de flores, ele inclui uma dedicatória em versos, na qual se dirige de maneira afável àqueles que fizeram uso de seus serviços: "O Valerio aos seus freguezes / Querendo mostrar gratidão, / Da-the o rosto de mil formas / Que é espelho do coração". Infelizmente, o Museu Paulista não conta com os negativos que geraram essas imagens impressas nos cartões de visita, o que nos impede de avaliar os detalhes da montagem. O papel em que foi impresso o buquê é texturizado, dificultando a apreciação dos rostos menores.

Já no caso das treze expressões faciais, a presença de uma cópia em papel fotográfico no acervo da Biblioteca Nacional nos permite descer aos detalhes. Valerio se aproxima do burlesco, ao buscar um efeito que tende ao cômico por meio do gesto, neste caso, concentrado no rosto, na inscrição dos sentimentos, o rosto como "espelho do coração", voltaremos com mais ênfase a essa questão. " Em Os trinta Valérios, a expressividade se expande para além do rosto, no sentido das mãos, usadas como extremidades comunicativas do corpo. É também o gesto de tocar, seja um instrumento, violino, piano, cello, batuta, seja um objeto, partitura, xícara de café, bule e bandeja, guarda-chuva, cartola ou jornal. Mesmo as mãos que não tocam se expressam sobremaneira, em um balé inesperado.

As treze expressões faciais não foram obtidas por meio de fotomontagem. Elas são resultado da múltipla exposição ao longo de uma banda panorâmica, tornada possível pela construção de uma máquina concebida pelo próprio fotógrafo com o intuito prévio, como comprova o sistema de indexação da Biblioteca Nacional: "Anotações manuscritas no livro de registro patrimonial (1916/1924): 'Tres provas do novo processo photographico de Valerio Vieira Photo. Photographias... - machina construída por Valério Vieira'". A traquitana resulta em uma inesperada elaboração em perspectiva. Os rostos crescem das laterais para o centro, mas o rosto central não está efetivamente sobreposto aos dois rostos
11. Sobre o burlesco no cinema, cf. Le cinéma burlesque ou la subversion par le geste, de Emmanuel Dreux (2007), e Le burlesque ou la morale de la tarte à la crème, de Petr Kràl (2007). 
vizinhos. A sobreposição se dá por meio da iluminação lateral, que vem da esquerda para a direita. Ao iluminar o rosto, a parte posterior do busto fica no escuro, possibilitando a sobreposição com o personagem seguinte.

Além do autorretrato, existem no acervo da Biblioteca Nacional duas outras imagens obtidas com a mesma câmera. Uma delas mostra uma menina em treze expressões dispostas da mesma maneira que o retrato múltiplo de Valerio, embora sua atuação fique muito aquém, apresentando poucas variações de sentimento. A outra imagem traz duas figuras masculinas dispostas em três poses individuais cada e uma imagem central em que os dois se entreolham (Figura 4). Outra vez, deslizamos deliciosamente ao território do burlesco, no qual a gestualidade facial se exprime de maneira cômica, histriônica, rocambolesca. É extremamente eficaz a disposição das expressões obtida pelo fotógrafo ao longo da tira panorâmica, sendo que os bustos individualizados parecem conversar entre si em uma dinâmica troca de olhares.

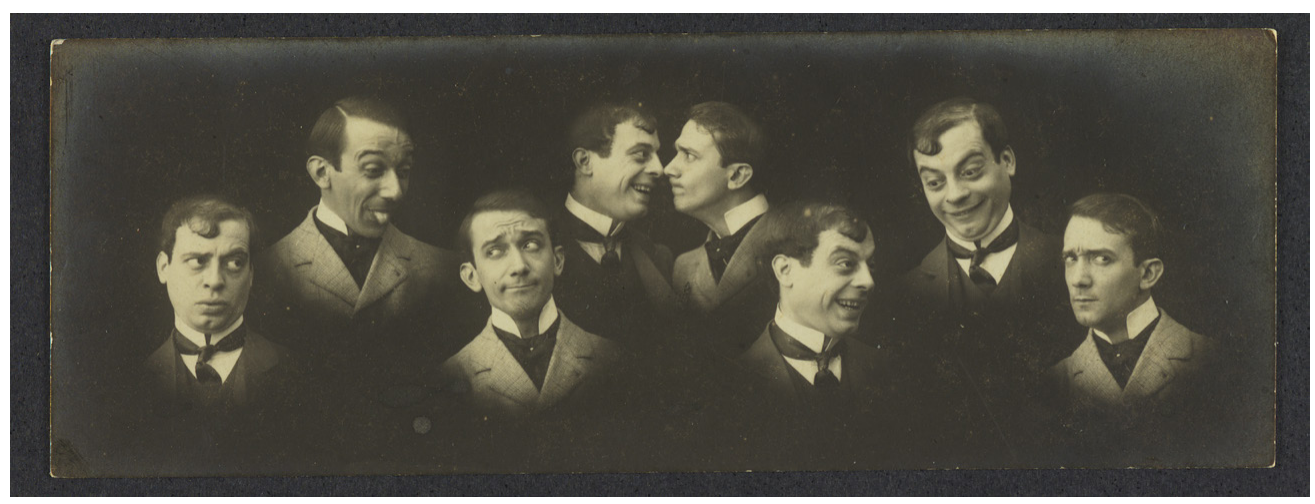

Figura 4 - Expressões Faciais em Múltipla Exposição: rostos masculinos (s.d.), Valério Vieira. Anotações manuscritas no livro de registro patrimonial (1916/1924): "Tres provas do novo processo photographico de Valerio Vieira Photo. Photographias... - machina construída por Valério Vieira". Fonte: Acervo Biblioteca Nacional.

Valério Vieira inicia sua trajetória como fotógrafo no Rio de Janeiro. Nascido em Angra dos Reis (RJ), no dia 16 de novembro de 1862, vai para a capital do Império juntamente com seu irmão em 1875, com a intenção de estudar. Entre 1876 e 1884 provavelmente teria frequentado a Escola de Belas Artes, onde aprendeu fundamentos de pintura. Após trabalhar como assistente no estúdio de José Ferreira Guimarães, muda para Pindamonhangaba (SP), em 1887, e casa com a segunda esposa em Taubaté (SP), em 1889. No mesmo ano muda novamente, para Ouro Preto (MG), onde permanece até 1894, quando se estabelece definitivamente em São Paulo. É na capital paulista que ele vai atingir o ápice da carreira. Em 1896, abre estúdio no coração comercial de São Paulo, à rua 15 de Novembro. Inicialmente administrado em parceria com Agiar, com o nome de "Photographia Valério \& 
Aguiar", o estúdio assume o nome "Photographia Valério" em 1900, quando o fotógrafo começa a ganhar proeminência profissional. ${ }^{12}$ Em 1903, Valerio viaja para Paris e, ao retornar, vira charge na revista Vida Paulista. ${ }^{13}$

$\bigcirc$ auge parece vir logo na sequência, com a medalha de prata na Exposição Universal de Saint Louis, em 1904, e a realização da primeira exposição fotográfica individual que se tem notícia na história da fotografia brasileira, em 1905, no Salão Progredior, em São Paulo. Monica de Junqueira Camargo e Ricardo Mendes resgatam notícia publicada na revista Santa Cruz com a cobertura do evento, acompanhada de duas imagens fotográficas. Uma das imagens apresenta um salão pesadamente decorado de obras, com parede forrada de grandes retratos. Não é possível distinguir se se tratam de fotos ou pinturas. No canto direito, uma luz parece emanar da parede para a qual um espectador lança seu olhar (Figura 5). Trata-se do Primeiro panorama de São Paulo, concebido naquele mesmo ano e considerado à época como recorde mundial de tamanho de fotografia em um só papel, medindo $11 \times 1,43 \mathrm{~m}$.

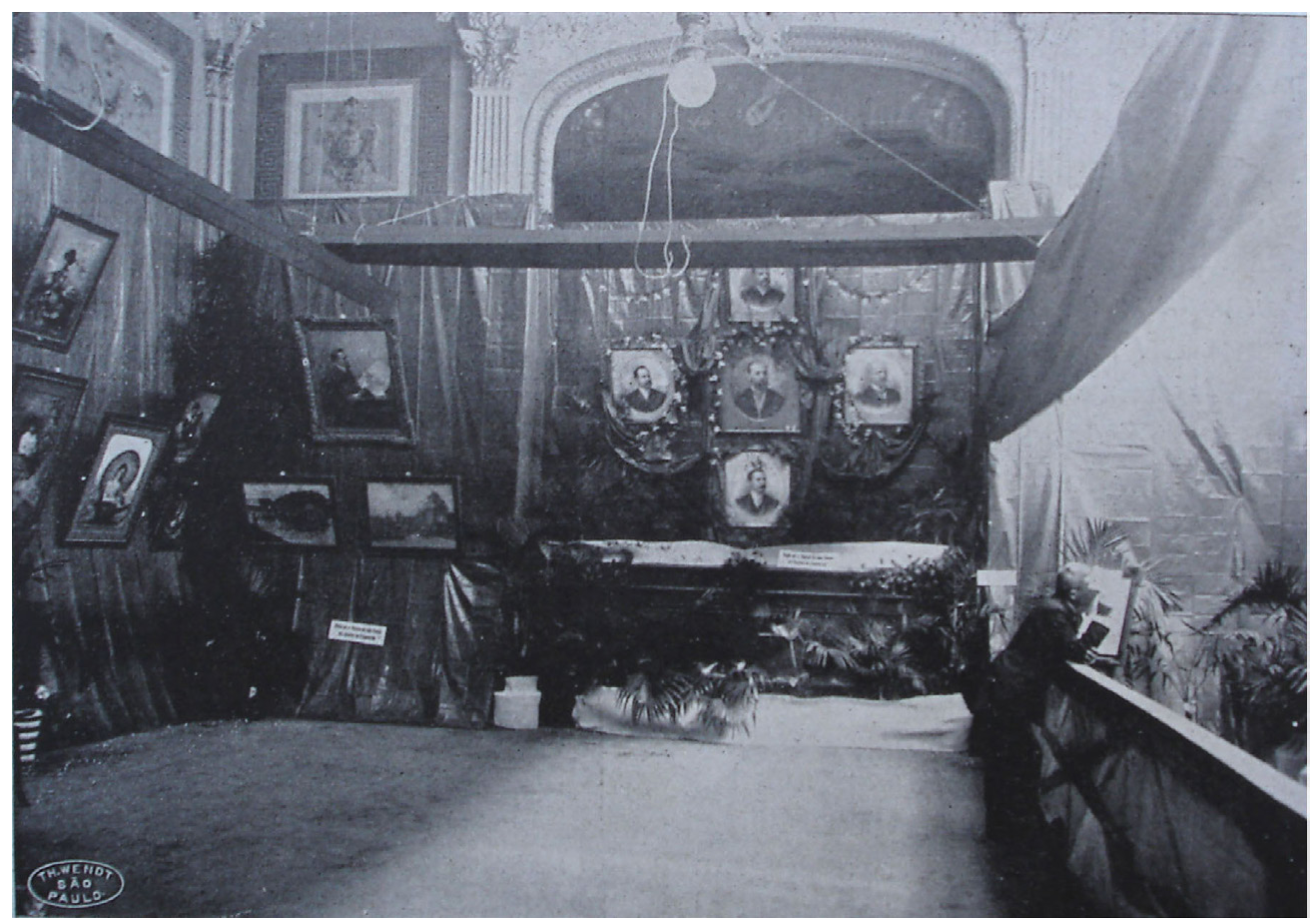

Figura 5 - Imagem da exposição de Valério Vieira no Salão Progredior. São Paulo, 1905. Reproduzido da revista Santa Cruz, v. VI, n. 4, 1906. Selo de TH. Wendt São Paulo. Primeira exposição individual de um fotógrafo que se tem notícia no Brasil. Fonte: Acervo Sonia Balady.
12. "Como os demais estúdios de renome, Valério investe continuamente na modernização e diferenciação de seus serviços, prática que indica provavelmente a existência de um mercado disputado. 'O sr. Valerio, por meio de uma combinação de luz fornecida por bicos Auer, conseguiu optimos resultados para a photographia á noite. As experiencias deram bom exito o que quer dizer que, d'ora em diante, o atelier funciona á noite.' (O Estado de S. Paulo, 7 abr. 1898, p. 2). A ampliação do horário além de permitir uma diferenciação no mercado, incluindo-se a própria novidade de obtenção do retrato por meio de luz artificial, marca um dos poucos registros precisos do grau de aparelhamento técnico no período". Mendes (2006, p 2).

13. A imagem mostra uma senhorita em trajes finos, que cumprimenta o fotógrafo, igualmente bem vestido. 
14. Segundo os autores, estavam expostas "algumas panorâmicas". "Em 1905, por exemplo, VALÉRIO VIEIRA (Angra dos Reis, 1862-1941) exibe no salão PROGREDIOR grandes panorâmicas, entre elas a da Fazenda Santa Gertrudes e o primeiro Panorama de S. Paulo. No período, é a mostra com maior número de registros na imprensa e a única da qual se possui imagens do evento. Essas fotos documentando a exposição revelam a semelhança da montagem com as exposições de artes. A presença de paredes forradas com tecidos e a distribuição dos quadros são aspectos comuns, por exemplo, à $1 \mathrm{a}$ Exposição Brasileira de Belas Artes, realizada no Liceu de Artes e Ofícios, no início dos anos 10". Camargo; Mendes (1992, p. 25-26).

15. Ricardo Mendes (2006) foi o primeiro historiador de renome a pesquisar de forma mais aprofundada a relevância de Valério Vieira em sua época, a partir de minucioso levantamento realizado na imprensa de São Paulo. Devemos a Sonia Balady o mais amplo e documentado levantamento biográfico sobre Valerio Vieira. O arrazoado de sua trajetória aqui realizado utilizou a dissertação de mestrado de Balady (2012), defendida na Universidade de São Paulo, como principal fonte de informações.

16. A única fotomontagem de maior monta produzida depois disso foi o painel da Legislatura de 1923 a 1926 , da Câmara Municipal de São Paulo. Balady (2012, p 185).
A segunda foto mostra quatro espectadores que posam justamente diante da panorâmica, quando percebemos que a obra foi montada em moldura e havia nicho especialmente concebido para sua exibição, incluindo iluminação própria (Figura 6). ${ }^{14}$ Os personagens, curiosamente, parecem ter saído de Os trinta Valérios. Embora se trate claramente de pessoas distintas entre si, a maneira de portar 0 bigode nos remete diretamente a Valério Vieira e seus personagens. Percebe-se um ímpeto de expositor no fotógrafo proeminente que, a partir de 1907, passa a ter espaço permanente para mostrar seu trabalho no Salão Progredior. ${ }^{15}$

Valerio também conheceu a consagração internacional. Ao participar da Feira Internacional de Turim, na ltália, com uma série de cartões postais do Rio de Janeiro e de São Paulo, é agraciado pelo governo italiano com o título de Cavagliere della Corona. Sua circulação na alta sociedade paulistana e a produção profícua parecem arrefecer a partir do início dos anos 1920, quando muda seu estúdio para - Bairro do Cambuci. Em 1922, Valerio se lança em uma das últimas empreitadas de fôlego de sua trajetória fulgurante, o Segundo panorama de São Paulo. ${ }^{16}$

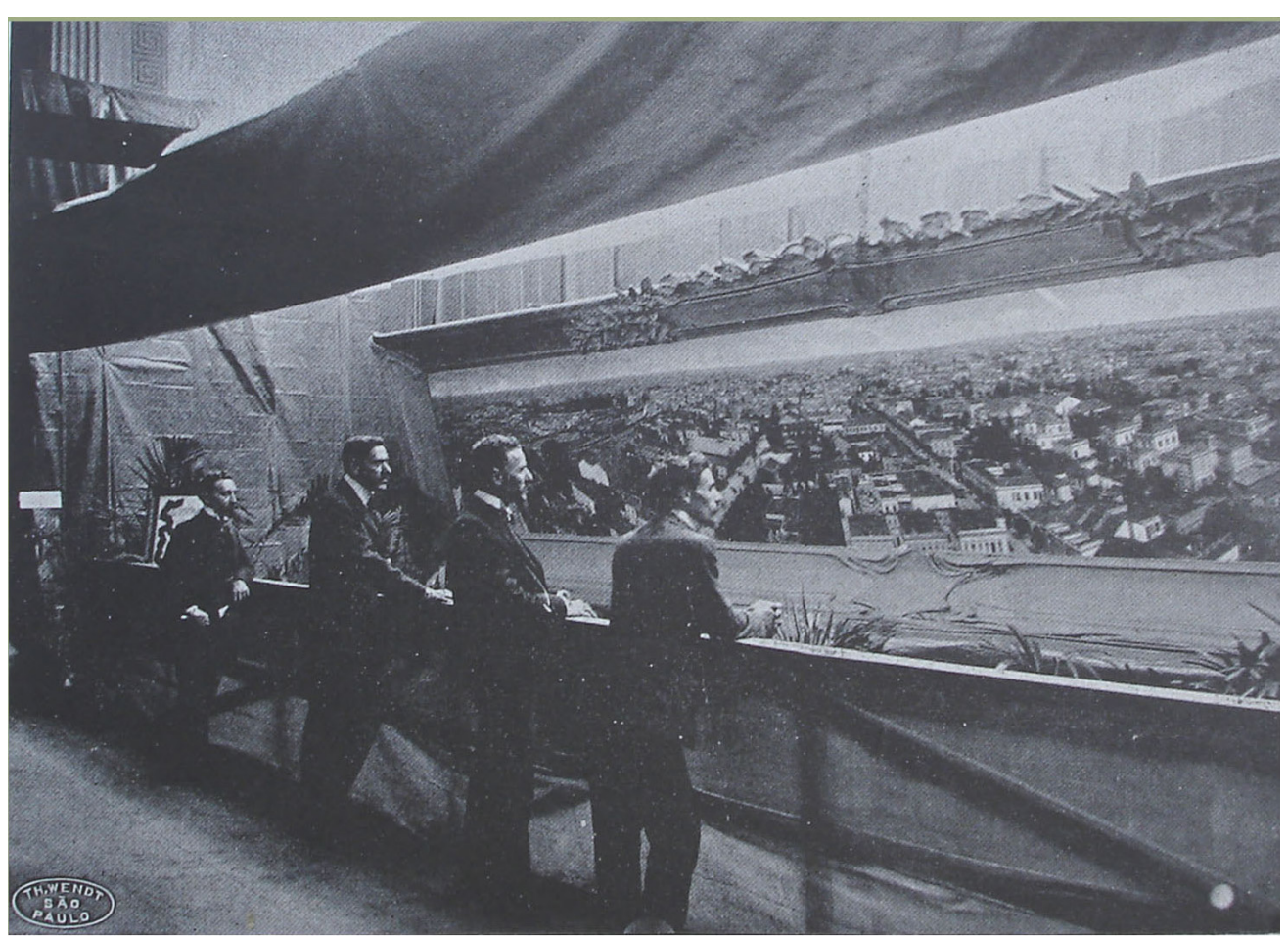

Figura 6 - Imagem da exposição de Valério Vieira no Salão Progredior. São Paulo, 1905. Reproduzido da revista Santa Cruz, v. VI, n. 4, 1906. Selo de TH. Wendt São Paulo. Fonte: Acervo Sonia Balady. 
Entre 1905, data da primeira imagem panorâmica, e 1922, quando se lança novamente na aventura, a paisagem urbana paulistana havia se transformado. De próspera e ainda provinciana capital de um estado rico em virtude do café, transformava-se em cidade cosmopolita, tendo recebido levas de imigrantes de inúmeros países. São Paulo se industrializava, em grande medida por conta dos esforços de guerra realizados pelas nações europeias durante a Primeira Guerra Mundial, que forçaram uma política de substituição de importações no Brasil. Embora com uma população ainda bastante inferior à da capital federal - em 1920, São Paulo contava com 579.033 habitantes e o Rio de Janeiro, com 1.157.87317 - a capital paulista ganhava proeminência econômica e logo se tornaria a "locomotiva" da economia brasileira, segundo um bordão publicitário entoado como mantra pelos governos locais. Candido Domingues Grangeiro estudou a propagação da "febre photographica" na São Paulo do final do século XIX. ${ }^{18}$ Militão Augusto de Azevedo (1837-1905) registra as transformações da cidade por meio de seu álbum comparativo, com duas séries captadas em 1862 e 1887, respectivamente. Quando cotejadas, as imagens revelam as transformações do tecido urbano; a capital paulista passa de vila a cidade. No entanto, mudanças mais efetivas ainda se dariam no início do século XX. Heloisa Barbuy estuda o comércio e o cosmopolitismo no centro da cidade, centrando sua análise no microterritório formado pelas três principais ruas comerciais: 15 de Novembro, Direita e de São Bento, que compunham o chamado Triângulo Paulistano. ${ }^{19}$ A historiadora cunha o termo "cidade-exposição", realçando a adoção de padrões importados de grandes centros urbanos europeus para forjar novas relações baseadas na exibição e na circulação de mercadorias.

A modernidade da grande cidade, que Walter Benjamin plasmou na figura do poeta Charles Baudelaire (182 1-1867), ${ }^{20}$ chegava com certo atraso ao Brasil. As vitrines, as passagens, o transporte público, a imprensa ilustrada, os salões de arte, uma série de novas experiências sensoriais ligadas sobretudo à dimensão visual emergem no tecido urbano. É nesse ambiente que o fotógrafo ganha proeminência como uma das mais prestigiadas profissões ligadas ao comércio da arte. Os estúdios de fotógrafos renomados estavam instalados nas principais artérias comerciais das grandes cidades. Fazer-se fotografar era febre alimentada pelas massas, a promoção da imagem pessoal ganha relevância inaudita, em uma era de aparências. A cidade é uma babel, nela se encontram pessoas provenientes de vários cantos, unidas e ungidas por uma vontade de consumismo e autorrepresentação.

Paulo Cezar Alves Goulart e Ricardo Mendes (2011), em "Noticiário Geral da Photographia Paulistana - 1839-1900", retraçam em detalhes o papel representado pela fotografia e os estúdios na vida da cidade ao longo do século
17. Dados do Instituto Brasileiro de Geografia e Estatística. Séries históricas disponíveis em: <https:// bit.ly/3axLpHR>.

18. Granjeiro (2000).

19. Barbuy (2006).

20. Cf. Livro das passagens (Benjamin, 1999) e Charles Baudelaire, um lírico no auge do capitalismo, (Benjamin, 1986). 
21. Noticiario Geral da Photographia Paulistana: 1839-1900 abre com uma sequência de imagens de Militão Augusto de Azevedo que atesta o intenso uso criativo da manipulação fotográfica sobretudo para fins recreativos. São imagens para as quais Militão envolvia sua clientela no jogo da ficção. O texto que acompanha dá uma medida da aura mágica envolvendo os estúdios fotográficos no século XIX. "Uma árvore genealógica, esse achado entre as imagens de Militão, mesclando desenho, gravura e traços marcados pela fotografia, é uma chave perfeita para tal cornucópia. Da vaidade de suas mulheres, que se exibem - aqui em cenas realizadas entre 1875 e 1885 - ao desleixo blasé masculino, algo distante da visão do retrato de então como estritamente sob o rigor da pose. Cabelos elaborados, flores singelas. Casais, amigos em mangas de camisa, garotas sentadas no chão do estúdio. Profissionais, com suas serras, seus pincéis - o pintor Tornoti - e suas Bíblias. Amigos que apontam, brincam com truques de dupla exposição, montagens, fantasmas (em companhia do poeta Martins Guimarães) e a grande mágica do século XIX: a fotografia." (Goulart, Mendes: 2011, p. 48). A dissertação de Eduardo Alves Covas sobre o fotógrafo português Francisco Brandão, atuante na cidade de Piracaia (SP) a partir de 1896, demonstra como a prática de trucagens e de cenas montadas envolvendo clientes e amigos faziam parte do repertório amplo dos fotógrafos retratistas em fins do século XIX. Cf. Covas (2009).

22. Dentre os principais livros acerca da obra do fotógrafo estão Militão $A u$ gusto de Azevedo, de Rubens Fernandes Junior, Heloísa
XIX. Valério Vieira aparece de maneira marginal, por conta de sua atividade terse iniciado na cidade somente em meados da década de 1890. A obra tem o mérito de estabelecer o mapa do centro de São Paulo, localizando os estúdios em seus endereços originais. Ela revela, por meio de imagens até então inéditas, que Militão Augusto de Azevedo, de quem Valerio realiza um retrato, era praticante inveterado de manipulações fotográficas. ${ }^{21}$ Pelo estúdio de Militão, que começou sua carreira como ator e carregou consigo as marcas desse início no teatro, passaram milhares de pessoas. Por conta dos preços populares que praticava e de suas iniciativas de documentação da paisagem urbana, foi um dos mais profícuos fotógrafos em atividade no período. Ao contrário de Valerio, do qual restam poucas informações documentadas e poucas obras reunidas em acervos institucionais, Militão deixou fartos vestígios acerca de sua atuação, que facilitou o surgimento de diversas pesquisas sobre sua obra. ${ }^{22}$

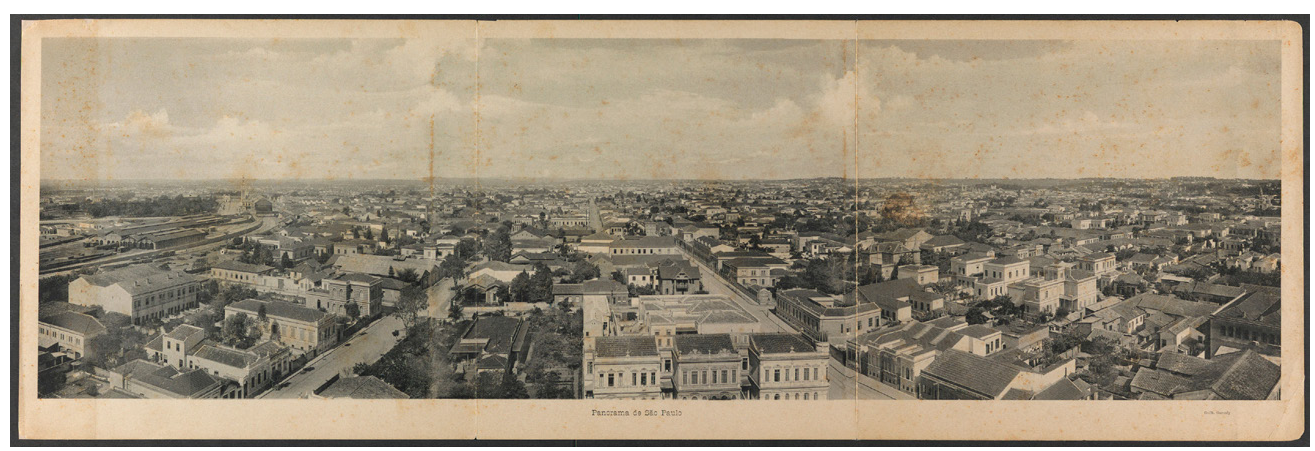

Figura 7 - Panorama de São Paulo (c. 1902), Guilherme Gaensly. Publicado no álbum Lembrança de São Paulo. Foto 49. Fonte: Acervo Biblioteca Nacional.

Há que se mencionar também Guilherme Gaensly, fotógrafo de origem suiça de idade um pouco mais avançada que Valerio, que ałuou em São Paulo na mesma época. Gaensly chegou a ter um estúdio vizinho ao de Valerio, na rua 15 de Novembro, antes de mudar-se para a rua Boa Vista, em 1916.23 Ele se engajou na produção de cartões postais, tendo documentado a cidade de São Paulo com grande intensidade ao longo da primeira década do século XX.24 Em 1902, elabora o álbum Lembrança de São Paulo, composto de 49 imagens, sendo uma panorâmica. Suas fotografias também circulam intensamente em revistas ilustradas. Boris Kossoy demonstra a que ponto a abordagem de Gaensly se imbrica com discurso oficial acerca da cidade, propagandeado pelas elites locais, que transforma o espaço urbano em "vitrine de suas fantasias europeizantes". ${ }^{25}$ Os bondes elétricos e os postes de luz passam a adornar as ruas, a cidade colonial é transformada com a construção de edifícios suntuosos em estilo neoclássico, os mesmos edifícios que serão vedete das imagens de Gaensly. ${ }^{26} \mathrm{O}$ panorama incluso 
no álbum Lembrança de São Paulo, de 1902, é realizado do mesmo ponto de vista que Valerio revisitaria em 1907 e 1922, do alto da torre do Santuário do Sagrado Coração de Jesus, no bairro dos Campos Elíseos, obtendo uma imagem com maior ângulo de cobertura (Figura 7). A série de cartões postais que Valerio cria em 1911 também se aproxima bastante da abordagem de Gaensly.

Observa-se, tanto nas panorâmicas como nos cartões postais produzidos por Guilherme Gaensly e Valério Vieira, uma aproximação dos ideais da elite paulista. Além de uma inserção comercial de suas vistas, é preciso refletir sobre o quanto elas poderão ter contribuído para a construção de um ideal de cidade, ou de uma cidade idealizada. Por trás da aparência de objetividade e de neutralidade, essas imagens carregam em si um determinado olhar, um ponto de vista concebido de maneira intencional. Os membros da elite paulista também frequentavam os estúdios mais renomados da cidade e junto a eles encomendavam obras, como as realizadas por Valerio aos poderes Judiciário e Legislativo. Por seu estúdio passaram juízes, advogados, políticos, fazendeiros, médicos, engenheiros, uma série de profissionais ligados a estamentos da burocracia governamental e à burguesia. São contatos dessa natureza podem ter contribuído a Valerio para que mesmo se lançasse em empreitadas como as que resultaram nas duas imagens panorâmicas de São Paulo, que contaram com aporte de dinheiro do governo local. Exemplo disso é o retrato que Valerio realiza de Manoel Joaquim de Albuquerque Lins (1 8521923), constante no acervo da Biblioteca Nacional. Político de longa carreira, foi presidente do Estado de São Paulo entre 1908 e 1912. Ele posa de smoking e gravata borboleta, em frente a um fundo finamente pintado. ${ }^{27}$

Embora tenha nascido no Brasil, Valério Vieira figura ao lado de outros fotógrafos de origem italiana na vanguarda da produção fotográfica na São Paulo dos primeiros anos do século XX. ${ }^{28}$ Seu nome está envolvido com os primórdios do fotojornalismo na cidade, ao publicar fotos de acontecimentos históricos relevantes nas páginas do jornal $O$ Estado de S. Paulo nas décadas de 1910 e 1920, como apontou a pesquisadora Telma Madio. ${ }^{29} \bigcirc$ envio de fotografias à imprensa para publicação fazia parte de uma troca. $\bigcirc$ fotógrafo cedia sua imagem e fazia seu nome circular, atraindo clientes ao seu estabelecimento. Aurélio Becherini 11879 1939) especializou-se nesse tipo de trabalho, logo se afastando do ateliê para assumir-se como fotógrafo "documentarista-cronista" de uma cidade em plena transformação. ${ }^{30}$ Becehrini ficou conhecido como o primeiro fotojornalista de São Paulo, seguindo os passos abertos por Augusto Malta no Rio de Janeiro. ${ }^{31}$

○ caso de Vincenzo Pastore (1865-1918) é parecido. Imigrante italiano como Becherini, se estabeleceu como um dos principais retratistas da capital paulista. Paralelo ao trabalho no estúdio, desenvolveu preciosa documentação das ruas de
Barbuy e Fraya Frehse (2012); Militão Augusto de Azevedo: fotografia, história e antropologia, de Íris Araújo (2010); e Militão Augusto de Azevedo: São Paulo nos anos 1860, organizado por Pedro Corrêa do Lago (2001).

23. "Um novo circuito fotográfico muito mais dinâmico desenhava-se na urbe paulistana. Espanta a proximidade de alguns desses estabelecimentos, dividindo algumas vezes a mesma calçada, dando vistas da acirrada disputa pela clientela [...] Na Rua Direita e na XV de Novembro, as de maior destaque no Triângulo Central, G. Sarracino, com estúdio no número 20, tinha à frente Valério Vieira, instalado no número 19; adiante, na calçada ímpar, localizava-se a famosa casa de produtos fotográficos Stolze \& Stuck, ocupando a numeração 29 , de onde se observava o número 28 , onde atuava Guilherme Gaensly." Beltramim (2015, p. 69-71).

24. "Nesta primeira década do século $\mathrm{XX}$, o trabalho dos fotógrafos que atuam na cidade de São Paulo raramente é identificado e sistematizado como ocorre nas séries de Gaensly. [...] A atitude empreendedora de produzir diferentes edições autorais utilizando diversos processos tecnológicos de impressão garantiu não só um diferencial para o trabalho de Gaensly como sobretudo a permanência de sua identidade na história da fotografia brasileira." Fernandes Jr. (2011, p. 54).

25. "As imagens de Gaensly foram fartamente utilizadas pelas primeiras publicações ilustradas, oficiais ou não, num contexto promocional, interessadas em divulgar a imagem do Estado de São Paulo no plano internacional. Gaensly, de sua parte, veicularia amplamente sua produção através de cartões postais que, como já vimos, 
se encontravam em pleno apogeu. Se, por um lado, enquanto fotógrafo proprietário de um estabelecimento comercial, as vistas urbanas e rurais se incluem em sua atividade profissional constituindo-se no seu meio de vida, por outro, ele colaborou definitivamente para a construção da imagem oficial da cidade: aquela idealizada pelas elites e pelo Estado [...]". Kossoy (1999, p. 69-70).

26. "Neste cenário não há mais lugar para os vestígios coloniais que encontramos nas imagens de Militão Augusto de Azevedo, o pioneiro das vistas urbanas da cidade de São Paulo. Nas fotos de Gaensly a arquitetura colonial é arrasada cedendo espaço às mansões de estilos consagrados, 'civilizados' e às edificações públicas neoclássicas. O governo paulista materializa seu projeto de modernidade através de marcantes reformulações na infra-estrutura, nos transportes e na urbanização de novas áreas. Era fundamental para a classe dominante eliminar as marcas da cidade provinciana de antes, identificadas com o atraso e apresentá-la com uma nova feição, européia.” Kossoy (1988, p. 21). Guilherme Gaensly produz enorme acervo para a companhia de energia elétrica Light, posteriormente publicado no livro Gaensly no acervo da Light: 1899-1925 (Dietrich: 2001).

27. Outros retratados por Valério no acervo da B.N.: Dr. Arnaldo Vieira de Carvalho (1867-1920), Diretor da Faculdade de Medicina, Gustavo Figner, um dos pioneiros da indústria fonográfica no Brasil, Rodolfo Nogueira da Rocha Miranda (1862-1943), outro político, foi deputado e ministro da Agricultura no governo Nilo Peçanha, entre 1909 e 1910.
São Paulo, chegando inclusive aos bairros periféricos, lugares de passagem entre o ambiente urbano e o rural. ${ }^{32}$ Essa dimensão humana da cidade parece passar longe das lentes de Valério Vieira e de Guilherme Gaensly, que reduzem os transeuntes a uma dimensão secundária diante da proeminência do espaço urbano.

A irreverência dos cartões de vołos de Valério Vieira indica a medida de sua originalidade, mas essa não foi, igualmente, uma invenção sua. Quando passou a atuar pela casa Carneiro \& Gaspar em São Paulo, Militão Augusto de Azevedo fez circular pela cidade um carte de visite no qual se representa de forma caricata, com a cabeça muito maior que o corpo e segurando nas mãos cartão com a marca do estúdio. Do lado esquerdo, ele posicionou um quadro, estabelecendo criativo jogo de espelhamento e projeção. Michelle Rizzo (1 869-1929), mais um italiano a conquistar farta clientela paulistana, também nos legou exemplar de um cartão de Boas Festas, realizado em 1906, no qual apresenta o seu estúdio. Esse tipo de imagem habita um espaço em que o fotógrafo pode exercitar a criatividade mais livremente, representando a si próprio, em seu ambiente de trabalho, com vistas à clientela.

A São Paulo que Valerio e sua geração "herdam" de Militão é uma cidade de maior proeminência econômica, que havia dado passos largos em direção à modernidade. ${ }^{33}$ Entre o Primeiro panorama de São Paulo, de 1905, e o Segundo panorama de São Paulo, de 17 anos depois, o horizonte da metrópole nascente se cobre de chaminés. ${ }^{34} \mathrm{~A}$ industrialização se descobre ao percorrer a imagem, e o trem que sai da Estação da Luz parece reverberar o sentimento de progresso. Mas a São Paulo de 1922, ao menos a São Paulo que Valerio registra em sua panorâmica, não parece ser uma cidade intensamente habitada. Talvez pelo ponto de vista escolhido, que não abrange a região central da cidade, mas se dirige à periferia. Em suas amplas ruas, poucas pessoas passam, os bondes, o traçado das ruas e as intermináveis fachadas conferem as linhas de força da imagem. $\bigcirc$ retoque resulta em uma sensação de progresso controlado, uma cidade "limpa" e industrializada (Figura 8).

O Primeiro panorama de São Paulo foi exibido na Exposição Nacional em homenagem ao Centenário da Abertura dos Portos, em 1908, onde obteve o Grand Prix. Estava exposto em um pavilhão anexo ao do estado de São Paulo. ${ }^{35}$ Não se sabe do paradeiro dessa primeira obra. O Segundo panorama foi exposto na mostra do Centenário da Independência, no Rio de Janeiro, em 1922. Após cinco décadas "esquecido", foi redescoberto no final dos anos 60 e incluído por Pietro Maria Bardi na exposição comemorativa dos 50 anos da Semana de Arte Moderna, realizada no MASP em 1972. 


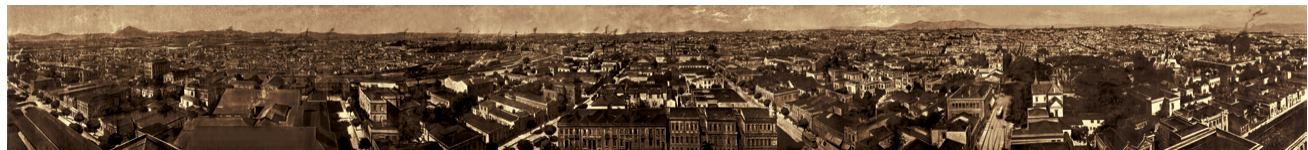

Figura 8a: Segundo panorama de São Paulo (1922). Valério Vieira. Fotografia retocada a óleo. (Restauração coordenada por Florence Maria White de Vera e patrocinada pela Kodak Brasil, em 1999|. Tamanho original: $16 \times 2$ metros. Fonte: Museu da Cidade de São Paulo - Casa da Imagem. Créditos fotográficos da reprodução: Fausto Chermont

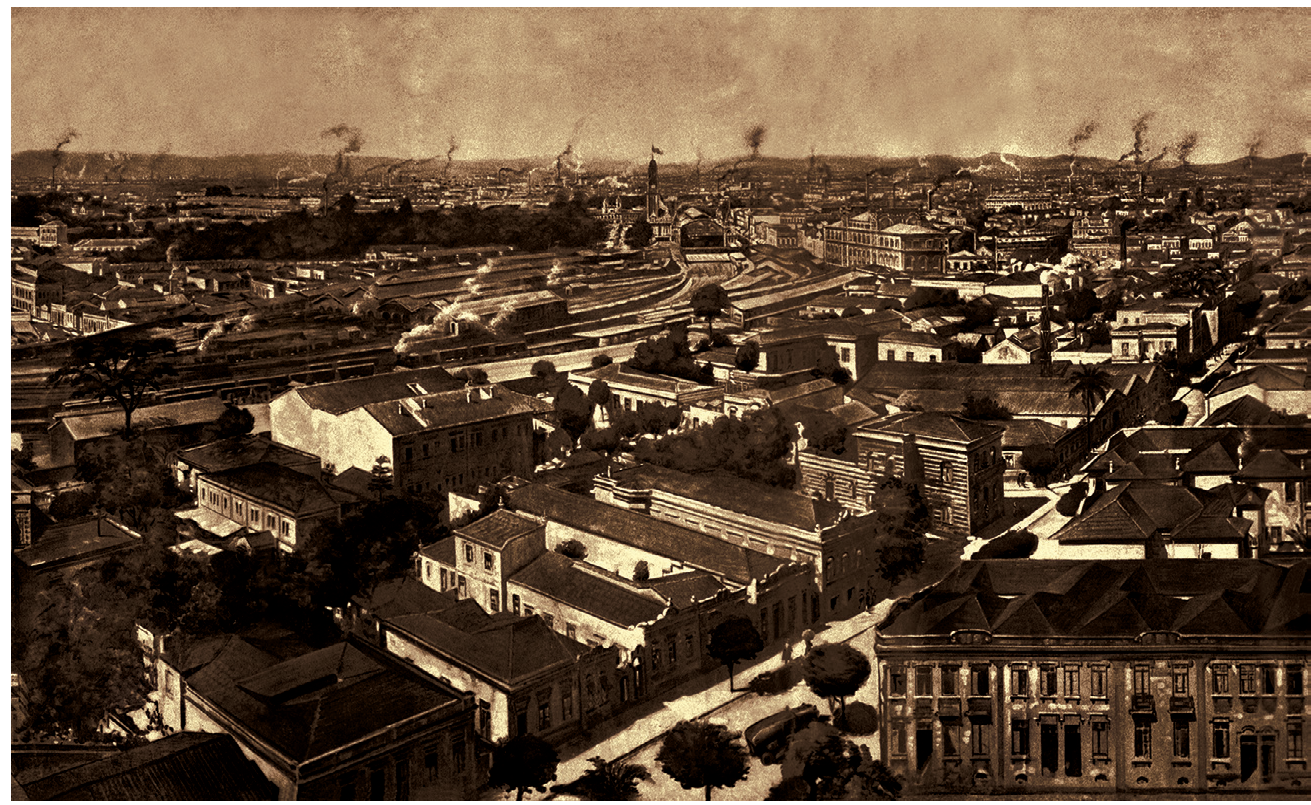

Figura 8b - Segundo panorama de São Paulo (1922) - Detalhe. Valério Vieira. Fonte: Museu da Cidade de São Paulo - Casa da Imagem. Créditos fotográficos da reprodução: Fausto Chermont

Para relatar a feitura do segundo panorama, foi publicado um folheto, pela Off. Graphicas Monteiro Lobato \& Cia., que circulou juntamente com a obra (Figura 9). ${ }^{36}$ Em tom laudatório, o texto exalta os desafios enfrentados pelo "artista nacional" face a todas as dificuldades encontradas em um país periférico. Conta o folheto que as duas panorâmicas de Valerio representaram dois sucessivos recordes mundiais de tamanho de fotografia em um só papel. Medindo $16 \times 2$ metros, a segunda panorâmica foi financiada pela Prefeitura Municipal e tomou um ano de trabalho do fotógrafo, desde sua concepção até a produção do papel, revelação e retoque. Abrangendo um ângulo de 180, a imagem foi realizada a partir de cinco fotografias tiradas sucessivamente e posteriormente montadas em uma só tira. Grandes produtores de papéis fotográficos foram consultados, sem sucesso, sobre a possibilidade de fornecerem o papel. Valerio teve então de produzir o próprio papel fotossensível, em mistura de trabalho artesanal e experimento científico. Vejamos como o folheto descreve, em sua linguagem peculiar e bastante datada, a complexa engenharia:
28. "Outro sinal de prestígio social pode ser sua presença na volumosa obra Il Brasil e gli Italiani publicado pelo Fanfulla em 1906. O extenso painel sobre o país, destacando a presença italiana, inclui breve comentário no segmento Arti ed Artistici, que dedica metade do espaço à obra do fotógrafo [...] Vieira é citado em conjunto com os fotógrafos Vollsack e Gaensly, além dos nomes mais expressivos de origem italiana. Profissionais dessa origem estão presentes na cidade a partir de meados da década de 1890 como Michele Rizzo (1869-1929), Oreste Cilento e Giovanni Sarracino." Mendes (2006, p.5).

29. Madio (2007).

30. Fernandes Jr. (2008, p. 2).

31. "Enquanto Augusto Malta é considerado o primeiro repórter fotográfico do país, por ter sido contratado em 1903 pelo prefeito Francisco Pereira Passos, do Rio de Janeiro, para documentar a construção da Avenida Central, Becherini é tido como o primeiro fotojornalista da imprensa paulistana. O Estado de S. Paulo, por ocasião do seu falecimento, publicou extensa nota de condolências em maio de 1939, na qual registra: 'Artista da photographia foi $o$ primeiro repórter photographico na nossa imprensa. Durante muitos annos exerceu sua profissão neste jornal tendo aqui prestado os melhores serviços'." Fernandes Jr. (2008, p. 3).

32. Beltramim (2015, p. 45).

33. Pasquale Petrone escreve, em 1955: "Os cinqüenta anos já decorridos, no século atual, foram assinalados por um fato novo, cujas origens remontam à última década do oitocentismo: o surto industrial, que veio transformar a 'metrópole do café' ou 'a capi- 
tal dos fazendeiros' na dinâmica e movimentada metrópole industrial de nossos dias. [...] $\mathrm{Na}$ verdade, nos últimos 50 anos, importantes acontecimentos mundiais vieram repercutir extraordinariamente sôbre a capital paulista, fazendo com que nela surgisse seu grande parque industrial: a primeira Grande-Guerra (1914-18), a crise econômica decorrente do 'crack' de 1929 e a última conflagração mundial (1939-45)." Petrone (1955).

34. Aracy Amaral relata essas transformações. "Seria precisamente essa 'construção de cidades' a mola fenomenal que daria a São Paulo o entusiasmo e a vibração necessários à liderança na renovação das artes no país. [...] O centro se deslocava. Longe já estava, ao finalizar a primeira década do século, a São Paulo vila colonial documentada fotograficamente por Militão Augusto de Azevedo em 1862 e 1887. Com uma área que 'orça por 35 milhões de metros quadrados' em 1913, o segundo decênio assistia à fase de expansão por excelência. Não havia mais fazendeiro que não houvesse na capital a sua chácara ou casa; o projeto, execução e abertura do Teatro Municipal era indício da febricitante movimentação humana nos inícios da industrialização da cidade." Amaral (1998, p. 67-68).

35. "Como a fotografia era muito maior do que os padrões normais, não foi possível apresentá-la no Pavilhão destinado aos trabalhos do Estado de São Paulo. Um anexo foi especialmente construído para abrigar a obra de Valério Vieira cujas dimensões tão diferenciadas causou muita curiosidade entre os presentes. [...]. Esse pavilhão nomeado de Annexo Paulista era um galpão sem janelas, com cobertura de duas águas, arrematada por lambre-
Montou, em sua propria residencia, um pequeno laboratorio chimico, onde estudou durante cerca de tres mezes, a formula da emulsão sensivel, cujo segredo de fabricação não é divulgado sinão em linhas geraes muito obscuras ahi conseguiu finalmente, com o auxilio do Snr. Conrado Wessel, obter a emulsão, ao mesmo tempo que estudava um processo mechanico para distribuil-a sobre o papel.

[...] Uma vez dada a emulsão, foi o papel pendurado em zig-zag para seccar, unica maneira de capacital-o dentro do limitado espaço em que se operava.

Feito o papel, seguiu-se a ampliação, operação esta de rigorosa precisão, o que foi feito em 7 successivos golpes, com luz solar, atravez de uma das maiores lentes do mundo, adquirida na Allemanha expressamente para este fim.

A revelagem da photographia uma vez impressa foi uma as grandes difficuldades a vencer. Dado o comprimento do papel, exigia o emprego de enormes bacias e o dispendio de centenas de litros de banhos, feitos com drogas carissimas. Este trabalho foi executado no espaçoso porão de um dos cinemas da Capital, com o auxilio de cerca de 14 pessoas e durante uma noite inteira. ${ }^{37}$

Todo esse enorme esforço seu deu em 1922, mesmo ano em que São Paulo assistia surpresa à Semana de Arte Moderna. São recorrentes as associações do nome de Valério Vieira ao modernismo, por conta do grau de inventividade e originalidade de sua obra, sobretudo Os trinta Valérios. ${ }^{38}$ Porém, ao observar a imagem panorâmica de Valerio, pressentimos que sua obra situa-se em um lugar de passagem, entre a fotografia oitocentista e o surgimento das vanguardas modernas. Ao contrapor a panorâmica de São Paulo, seu gigantismo e o aporte de dinheiro da Prefeitura Municipal na sua execução, que denota certo comprometimento com uma visão oficial propagandeada do progresso paulista, o tom exclamatório presente no folheto "O Record Mundial da Photographia" e todas os elogios que tece ao esforço do "artista local", com o discurso de Graça Aranha na abertura da Semana de Arte Moderna, percebemos em que medida Valério Vieira ainda estava ligado a concepções estéticas oitocentistas, período, por sinal, que conheceu o florescimento das imagens panorâmicas. A "vontade panorâmica" está ligada à uma pretensão de reprodução imersiva e totalizante da paisagem, seja "natural" ou urbana. ${ }^{39}$ Tal concepção está em franca oposição ao que propunha o movimento modernista, como podemos constatar ao revisitar as palavras proferidas por Graça Aranha no Teatro Municipal, no dia 14 de fevereiro de 1922, sobre a "emoção estética na arte moderna":

Para muitos de vós a curiosa e sugestiva exposição, que gloriosamente inauguramos hoje é uma aglomeração de "horrores". Aquele Gênio supliciado, aquele homem amarelo, aquele carnaval alucinante, aquela paisagem invertida se não são jogos da fantasia de artista zombeteiros, são 
seguramente desvairadas interpretações da natureza e da vida. Não está terminado o vosso espanto. Outros "horrores" vos esperam. Daqui a pouco, juntando-se a esta coleção de disparates, uma poesia liberta, uma música extravagante, mas transcendente, virão revoltar aqueles que reagem movidos pelas forças do Passado. Para esses retardatários, a Arte ainda é o Belo. 40

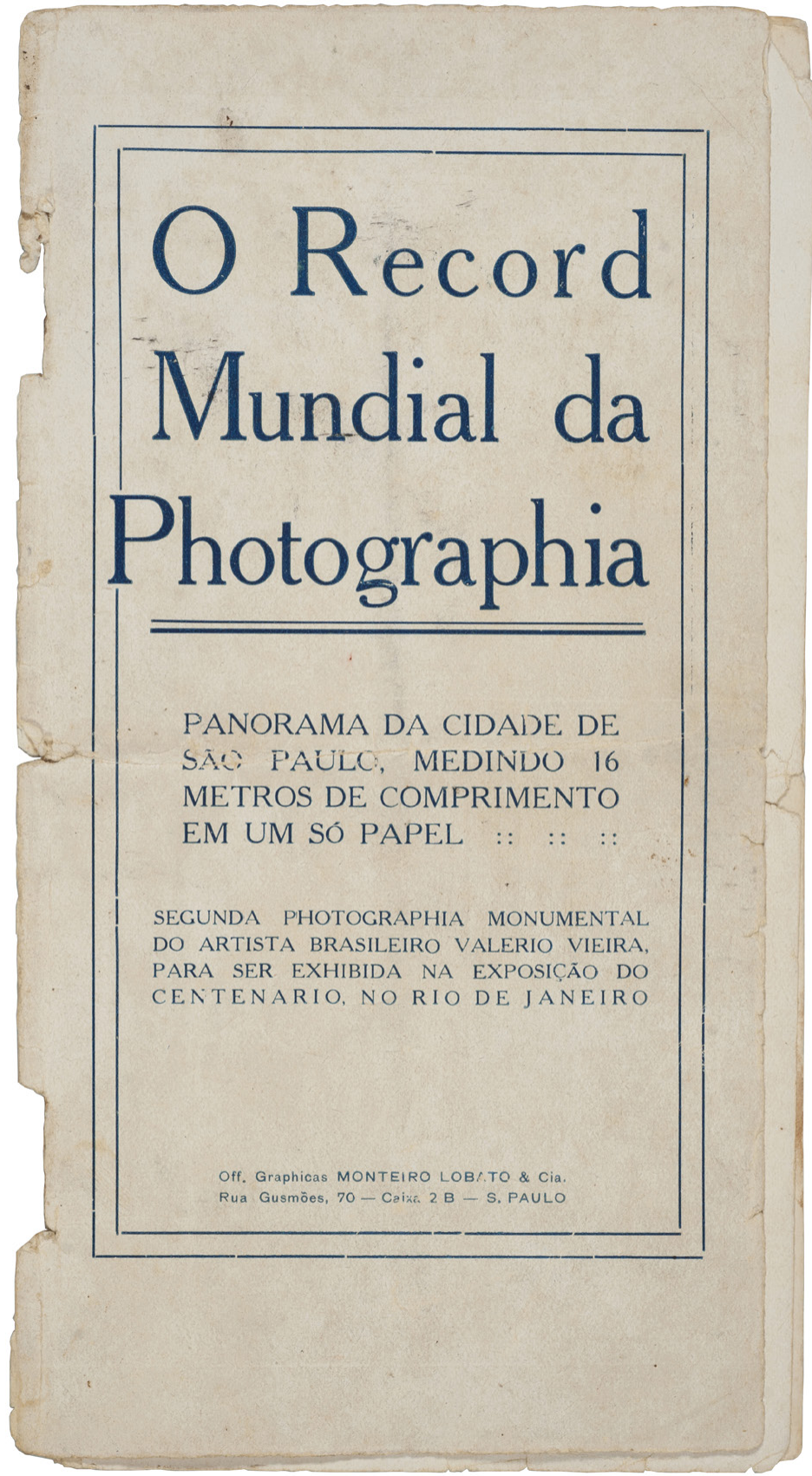

Figura 9 - Capa do folheto "O Record Mundial da Photographia" (1922). Sem autoria reconhecida. Publicado por Off. Graphicas Monteiro Lobato \& Cia. Fonte: Acervo Museu Paulista da Universidade de São Paulo. Créditos fotográficos da reprodução: Hélio Nobre e José Rosael. quins e cumieira no sentido longitudinal, no estilo chalé. Na fachada principal, de oitão, porta dupla encimada por bandeira e a inscrição: Panorama de S. Paulo do artista Valério Vieira." Balady, 2012, p. 116-117).

36. "Atendendo ao convite dos prefeitos Rocha Azevedo e Firmiano Pinto, Valério Vieira representou São Paulo no Centenário da Independência, em 7 de Setembro de 1922, no Rio de Janeiro, na Esplanada dos Castelos, com a nova cópia da fotografia 'Panorama de São Paulo', desta vez medindo $16 \times 2 \mathrm{~m}$. A exposição foi inaugurada oficialmente ás $16 \mathrm{~h} 30$ pelo presidente da República, Sr. Epitácio Pessoa, em sessão solene no salão nobre do pavilhão de festas. Antes de ser enviada para o Rio de Janeiro, essa fotografia foi exposta em São Paulo, em 6 de setembro de 1922 , no prédio $\mathrm{n}^{\circ} \mathbf{2 4}$ da rua São Bento, com a presença do prefeito e de representantes do Congresso do Estado. Durante a mostra do Centenário da Independência, o folheto ' $O$ Record Mundial da Photographia' era distribuído para os visitantes." Balady (2012, p. 124).

37. Folheto "O Record Mundial da Photographia" (1922, p. 9-10).

38. Pietro Maria Bardi chegou a selecionar Os trinta Valérios para a exposição comemorativa dos 50 anos da Semana de Arte Moderna, realizada no MASP, em 1972, como ele próprio indica nos livros "O Modernismo no Brasil" e "Em Torno da Fotografia no Brasil" Bardi (1978; 1986). A escolha causa surpresa, pois não há registro de que Valério Vieira tenha exercido algum tipo de influência sobre a geração modernista, quer seja nas artes plásticas ou na fotografia. Para Rubens Fernandes Júnior, 
"com certeza, sua obra tinha especificidades técnicas e estéticas que estavam à frente de seu tempo e pareciam antecipar o momento de inserção do Brasil na moderna era industrial." Fernandes Jr. (2002).

39. A produção de vistas panorâmicas remonta aos primórdios do século XIX, com o diorama construído por Daguerre na Passage des Panoramas, em Paris. Cf. Benjamin (1999, p. 5-6). Sobre a realização de panorâmicas no Brasil oitocentista, com ênfase no trabalho de Marc Ferrez, grande mestre do gênero, cf. "A Vontade Panorâmica”. Turazzi, 2005). Sobre a comercialização de vistas de maneira geral, cf. artigo de Solange Vaz de Lima. "O painel fotográfico gigante da cidade de São Paulo idealizado pelo fotógrafo Valério Vieira em 1905 [...] pode ser interpretado como um símbolo da disseminação desse gênero. Nos 20 primeiros anos do século $\mathrm{XX}$, além de postais e vistas estereoscópicas são editados cerca de vinte álbuns da cidade de São Paulo, inclusive uma série de álbuns comparativos (1914-1919) utilizando a produção fotográfica de Militão Augusto de Azevedo. Tão importante quanto a produção é o grau de circulação que essas imagens atingem: as fotografias editadas em álbuns ou postais figuram posteriormente em almanaques, revistas, livros, são enviados às exposições internacionais, enfim, consumidas por diversos setores e classes sociais." Fabris (1991, p. 70).

40. Amaral (1998, p. 268) [grifos nossos].

41. O livro de Helouise Costa e Renato Rodrigues, $A$ fotografia moderna no Brasil, publicado em 1987 e reeditado em 2004, segue sendo a obra referencial nessa área, ainda que cen-
Os trinta Valérios certamente se enquadra nesse "espírito zombeteiro" dos modernistas, mas a obra tem poucos pontos de contato, seja temáticos ou estéticos, com produções da fotografia moderna brasileira, cujas realizações no campo da fotomontagem apontam para uma destruição do espaço concebido pela perspectiva monocular. José Oiticica Filho, Geraldo de Barros, José Yalenti e Marcel Giró têm um forte apelo geométrico e abstrato. Jorge de Lima e Athos Bulcão operam, em suas colagens, por meio de criações oníricas, nas quais as variações de escala e de natureza entre as imagens são elemento essencial para obtenção de um estranhamento. Já os retratos surrealistas de Thomaz Farkas, embora igualmente performáticos, apontam para a decomposição do corpo em partes. ${ }^{41}$

Ainda que claramente imerso em uma modernidade, da qual extrai consequências e um repertório de referências significativo, forjando uma obra extremamente original, Valério Vieira não pode ser compreendido como um modernista avant la lettre. É importante frisar que tanto a modernidade, fenômeno social, como o modernismo, fenômeno artístico, ocorrem em intensidade e temporalidades muito distintas na São Paulo de Valerio, em relação às metrópoles que estão no centro do sistema capitalista mundial. Mas sua obra não está ancorada apenas no campo da fotografia e das artes plásticas, ela aponta para além, permitindo uma série de associações transmídia, com o cinema, o teatro e a música de sua época.

\section{DO MÁGICO AO BURLESCO}

Valério Vieira é contemporâneo do surgimento do cinema e certamente frequentou salas, assistiu a filmes. Chegou até mesmo a ser filmado, da sacada de seu estúdio na rua 15 de Novembro, por Conrado Wessel (1891-1993), quando documentava o centro da cidade com uma câmera de cinema Pathé, em 1908. Empreendedor especializado na produção de emulsões fotossensíveis, é Wessel quem vai ajudar Valerio na concepção do papel para o Segundo panorama de São Paulo, em 1922, diante da falta de fornecedores estrangeiros que pudessem atender à encomenda na época, como mencionado no trecho do folheto "O Record Mundial da Photographia" citado algumas linhas acima. ${ }^{42}$

Ao observar com atenção as principais obras de Valerio, constatamos uma proximidade com o processo criativo do cinema. São imagens compósitas cuja concepção se inicia antes da tomada das fotos, no planejamento da execução do projeto. Após o momento da tomada das fotografias, há todo um trabalho minucioso de montagem e acabamento. A fotomontagem envolve as três etapas do processo 
criativo em igual proporção: pré-produção, produção e pós-produção. É uma obra processual, distinta do "instantâneo", que está encerrado em si, como corte abrupto. Dentre todos os artistas produtores de imagens em sua época, talvez a maior proximidade encontrada com a irreverência de Os trinta Valérios esteja na comparação com um homem de cinema. Refiro-me a Georges Méliès (1861-1938).

A referência é inevitável, posto que Méliès realizou, na mesma época que Valerio, um filme cuja proposta é idêntica àquela desenvolvida em Os trinta Valérios, intitulado L'homme orchestre (1900). A lógica é exatamente a mesma: um homem se multiplica em todos os executantes de uma orquestra, sob os olhares estupefatos dos espectadores. Esse homem é o próprio fotógrafo/cineasta. Ele concebeu a cena para sua própria representação. Trata-se, portanto, de um autorretrato, o autor que finge, que surpreende, o autor-ator. Apenas ele, sozinho, vai fazer a máquina de imaginações funcionar, multiplicando-se em muitos. Além disso, há um cenário, o espaço é pensado, é medido, controlado; é construído.

Há diferenças evidentes que surgem por conta das mídias empregadas. Os trinta Valérios é uma imagem estática, cujo grau de controle na montagem é muito maior do que no plano cinematográfico. Méliès utilizou-se da técnica da sobreposição de negativos com fundo preto, expondo o mesmo rolo de filme sucessivas vezes e reencenando cada vez na pele de um novo personagem. Essa técnica impõe limitações, como a dificuldade em alinhar harmonicamente o movimento dos personagens - os músicos parecem completamente alheios entre si - e a menor margem para o trabalho com a profundidade de campo - todos os personagens estão posicionados no mesmo plano. Enquanto no filme de Méliès a multiplicação dos personagens se restringe aos músicos, na fotomontagem de Valerio ela se expande à plateia, aos serviçais, ao busto, aos quadros, e ao próprio fotógrafo, todos dispostos em profundidade e captados a partir de um ponto de vista especialmente construído. Em Méliès, a câmera é frontal e a decoração apenas emoldura os músicos. Enquanto Valerio pode experimentar mais do ponto de vista da expressividade de seu rosto, Méliès concentra-se no movimento do corpo. Ambos trabalham a gestualidade da música, porém em estratos distintos.

Há uma diferença importante entre a sobreposição de negativos e a montagem, em relação à textura da imagem final. A sobreposição gera efeitos fantasmáticos, alguns personagens parecem ligeiramente transparentes, enquanto que na colagem os contornos são nítidos e os personagens bastante destacados entre si. Como trabalhava sobre uma imagem única, Valerio pôde dedicar-se com esmero muito maior à mágica de criar uma ilusão crível, recortando e colando partes de diferentes imagens até chegar em uma composição ideal que pudesse refotografar, gerando um negativo no qual não se percebe emendas. Mas para trado no caso do Foto Cine Clube Bandeirantes e da chamada Escola Paulista.

42. Valério é filmado ocasionalmente por Wessel, em 1908. Quando os dois se conhecem para elaboração do papel fotossensível para o Segundo Panorama de São Paulo, em 1922, Wessel deve ter passado a Valério uma cópia do fotograma de seu filme sobre São Paulo em que a família aparece na sacada do estúdio. A neta de Valério, Maria Luiza Vieira, incluiu uma reprodução do mesmo no lote de documentos adquirido pelo Museu Paulista em 1992. Segundo Sonia Balady, o filme acabou incinerado em um incêndio ocorrido no estúdio de Wessel, restando apenas o fotograma como vestígio de sua existência. "Em 1908, Wessel estava documentando os acontecimentos do centro de São Paulo, atravessando-o em bonde aberto, com uma câmera Pathé de propriedade da Gaumont Films de Paris. Em uma destas sequências - no momento em que filmava a rua XV de Novembro - captou a figura de Valério na varanda de seu estúdio, olhando em direção à câmera de filmagem." Balady (2012, p. 121). 
43. Tomo emprestada a expressão de Gilles Deleuze (1985), para quem o cinema não deve ser considerado uma imagem em movimento, mas uma imagem-movimento, já que a incorporação do movimento se dá no interior da própria imagem, não se trata de algo externo, mas imanente.

44. Méliès já havia experimentado com a multiplicação por meio da decapitação em Un Homme de Têtes (1898). As cenas de decapitação assombram a história da arte. Basta pensar na recorrência com que a história de Judite e Holofornes foi pintada. Mas Méliès aborda a decapitação desde um princípio mágico. Trata-se de um antigo truque de ilusionismo $e$ prestidigitação, já praticado, por exemplo no teatro Robert-Houdin, no famoso número chamado décapité recalcitrante. Malthête; Mannoni (2008, p. 113). Em L'Ilusioniste Double et la Tête Vivante (1900), Méliès mistura a duplicação do personagem principal, representado por ele mesmo, e a decapitação de sua assistente de palco. Em Dislocation Mysterieuse (1901), promove o esquartejamento e a remontagem do corpo de um pierrot. Provavelmente há outros exemplos em sua vasta filmografia.

45. "Le Melomane é um exemplo perfeito da multiplicidade e do virtuosismo das trucagens inventadas por Méliès. Ele utilizava principalmente o arrêt de la caméra, as fusões, as máscaras para aparição e desaparição. Para esse filme, feito com sobreimpressões múltiplas, sete exposições do filme foram necessárias ao cineasta afim de aparecer sete vezes simultaneamente. A câmera, muito pesada, precisava ter estabilidade absoluta. O máximo de sobreimpressões é aqui obtido com os mate- realizar tal mágica de ilusionismo, Méliès contou com uma ferramenta muito mais poderosa: a imagem-movimento. ${ }^{43}$ Poderosa sincronicidade entre dois artistas contemporâneos entre si, que conheceram o sucesso em uma mesma época e que buscaram o que nas palavras de Valerio, citadas em The Strand Magazine, é definido como obter "o extraordinário apresentado de forma artística".

Há outros filmes de Méliès que exploram o mesmo princípio da multiplicação pessoal do personagem principal. Em Le Melomane (1903), ele desdobra a concepção original de L'homme orchestre para um outro cenário, com roteiro distinto, mas ainda assim profundamente ancorada na fusão de música e mágica por meio do cinema. Dessa vez, Méliès se apresenta como regente. A multiplicação de si se dá pela decapitação, com todos os "medos" e fantasmas que essa forma extrema de ação carrega consigo. ${ }^{44}$ Ele vai lançando aos fios de um poste suas cabeças, que criam a tessitura de uma partitura. Depois, passa a reger uma orquestra imaginária, acompanhado por um grupo de mulheres que também portam suas batutas e cartazes com as letras de notas musicais. $\bigcirc$ filme começa com Méliès mascarado. Ele apresenta à plateia as linhas gerais do número que irá representar, escreve em uma cartolina as notas musicais e aponta para os fios no alto do enquadramento, indicando como se dará a ação. Só então ele atira a máscara para fora do rosto e passa à ação propriamente dita, que se desenrola com sua própria face exposta. Aqui, o jogo se dá principalmente no nível da gestualidade, como no buquê de Valerio, na sobreposição das treze expressões faciais ou em Os trinta Valérios. Gestualidade que se expressa por meio do rosto, nas cabeças que flutuam, e do corpo, no Méliès que corre de um lado a outro para executar seu número. ${ }^{45}$

A multiplicação e a deformação do rosto são exploradas no filme L'Homme à la Tête de Caouchouc (1901). O personagem principal posiciona sua cabeça em um pedestal e, com uso de um fole de soprar, provoca seu inchamento. Depois, convida outro personagem maluco a fazer o mesmo. A cabeça acaba obviamente por explodir na cara dos dois, causando surpresa. Méliès também retoma a temática do personagem de "carne e osso" que se duplica no próprio retrato pintado e com ele interage, fazendo com que a pintura ganhe vida. Essa temática já havia sido explorada por Oscar Wilde em O retrato de Dorian Gray (1890), novela que teve grande repercussão na Inglaterra vitoriana. ${ }^{46} \mathrm{~A}$ autorrepresentação de um pintor que executa o ato criativo tem suas raízes mais profundas na história da arte ocidental, caso da célebre mise-en-abîme barroca de Velázquez em Las Meninas (1656). Em Os trinta Valérios, o bonhomme se vê representado incluso nos três quadros pendurados na parede, sendo que os dois das pontas apresentam seu rosto de perfil e o central o mostra de frente. As três imagens nos remetem aos experimentos de fotoescultura de Nadar e L. P. Clerc, sob o nome de "photostérie". 47 
André Galdreault dedicou parte significativa de sua trajetória teórica a tentar desvendar o "mistério" Méliès. Ele chegou à conclusão de que é equivocado pensar Méliès à luz do cinema narrativo ficcional que se tornaria hegemônico a partir do final da década de 1910.48 Suas referências encontram-se no século XIX, nos espetáculos de mágica, ilusionismo e prestidigitação. Sua atuação no teatro RobertHoudin e a posterior aquisição do mesmo, antes do surgimento do cinema, comprova que suas origens estão no espetáculo de mágica. ${ }^{49}$ Ao descobrir o cinema, Méliès descobre uma ferramenta a mais em seu repertório criativo. Ferramenta essa que logo ganharia importância central em sua produção, embora em seus filmes Méliès nunca tenha deixado de explorar as dimensões teatrais, tanto com relação à decoração, ao cenário, como com relação à sua atuação como personagem principal e à direção de outros atores, por vezes numerosos. Mesmo nos filmes mais "narrativos", como Voyage dans la Lune (1902), Méliès opera por meio de uma sequência de quadros, chamados por ele literalmente de "tableaux". ${ }^{50}$ Para Gaudréault, Méliès produziu um tipo de cinema que se limita aos poucos anos que separam o surgimento do cinematógrafo, em 1889, da normatização narrativa ocorrida ao longo das décadas de 1910 e 1920. Gaudréault chama esse tipo de criação de "cinema de atrações", termo que não deve ser confundido com o emprego realizado por S. M. Eisenstein em seus escritos sobre a "montagem de atrações".

É fato que as origens de Méliès estão no teatro Robert-Houdin, mas ele encontrou no cinema potencialidades inesperadas, tornando-se, talvez, o primeiro cineasta experimental da história. Essa conexão é realizada por Norman McLaren, em texto no qual aponta Méliès como o grande inventor de base de todas as trucagens empregadas até hoje no cinema: a dupla e a múltipla exposição, o uso de máscaras, a captura imagem por imagem, a alteração de velocidade e o truque chamado de "arrêt de camera", que consiste na parada de filmar e retomada no mesmo enquadramento, de maneira a propiciar um corte temporal entre dois planos. ${ }^{51}$ Grande parte desse repertório de trucagens deriva da fotografia recreativa, que é fundido de maneira surpreendente ao universo dos espetáculos de mágica para criar um gênero novo e de duração fugaz. ${ }^{52}$ McLaren menciona uma frase de Méliès, que conta muito sobre seu cinema: "Eu era ao mesmo tempo um intelectual e um trabalhador manual: o que explica porque eu me apaixonei tanto pelo cinema". ${ }^{53}$ Mágico e manipulador, Méliès tinha como meta a construção de ilusões, estava ligado ao theâtre de féerie, uma indústria extremamente artesanal, espetáculo criado quase inteiramente por um "exército de um homem só". 54 Ele assumia uma série de papéis em seus filmes, desde concepção do enredo até a execução e a apresentação. riais disponíveis à época." Bazou (2001, s.n.).

46. Em $O$ retrato de Dorian Gray, o personagem é pintado em um retrato que imortaliza sua beleza. Encantado com a própria imagem, o protagonista vende sua alma para que o personagem pintado envelheça em seu lugar e ele possa desfrutar de sua mocidade eternamente. A literatura fantástica é também uma invenção da segunda metade do século XIX, quando o público parece propenso a se afetar com histórias paranormais e extraordinárias. Méliès explora a temática do fantástico-espiritista em pelo menos três filmes, Évocation spirite (1899), Spiritisme abracadabrante (1900) e Le portrait spirite (1903). O livro The first man on the moon, de H. G. Wells (1901), foi publicado na França alguns meses antes de Méliès conceber Le voyage dans la lune (1902). Lembremos ainda da enorme popularidade conquistada por Jules Verne (1828-1905) com suas novelas de aventura, algumas encenadas inclusive por Méliès.

47. A revista La Science Française, publicada em 3 de fevereiro de 1899 , traz em suas páginas 17 e 18 um artigo sobre os experimentos de L. P. Clerc em parceria com o então octogenário Nadar. A publicação está disponível na íntegra no sítio Gallica, da Biblioteca Nacional Francesa. Disponível em: $<$ https://bit.ly/3h4YV7n>.

48. Gaudreault (2008).

49. O livro Méliès: magie et cinéma, com coordenação de Jacques Malthête e Laurent Mannoni (2008), aponta exatamente para essa direção, mostrando as relações entre Méliès e o universo da mágica e da prestidigitação no final do século XIX. 
50. O filme Voyge dans la lune é inspirado em uma ópera féerie homônima de Jacques Offenbach, apresentada no Châtelet, em 1877. O "roteiro" do filme é realizado a partir de uma série de desenhos de Méliès chamados por ele de tableaux (quadros). Cf. informações completas e farta documentação iconográfica em artigo de Thierry Lefebvre incluído na coletânea Méliès: magie et cinéma, organizada por Jacques Malthête e Laurent Manonni (2008).

51. McLaren ressalta a presença constante do acaso nas descobertas de trucagens realizadas por Méliès. Sobre seu papel como inventor dos truques de base do cinema, McLaren afirma o seguinte: "Ele descobriu e utilizou de forma imaginativa a maior parte dos efeitos cinematográficos de base. Mesmo estando longe de ter assistido a todos os filmes de Méliès, eu penso que ele é o primeiro a ter feito duplas e depois múltiplas exposições, máscaras e contramáscaras, fade in e fade out, tomada de vistas imagem por imagem, reduções de velocidade e acelerações." McLaren (2008, p. 3).

52. Clément Cheroux (2010, p. 99-114) é o primeiro a sugerir uma relação direta entre o cinema de Méliès e o repertório de trucagens da fotografia recreativa. Caroline Chik (2014) demonstra como o efeito obtido com o "arrêt de camera" tem relações com as chamadas fotografias animadas da estereoscopia.

53. McLaren (2008, p. 3)

54. O adjetivo féerique em francês é derivado de fée, que significa "fada". Tem o correspondente em português, "feérico", menos usado, cuja definição dada pelo dicionário Aurélio é a se-
Ele não era somente o seu próprio realizador, autor, roteirista, mas igualmente seu próprio construtor de cenários, pintor, coreógrafo, mecânico, inventor de trucagens, maquetista, figurinista, ator e multipapéis, montador e distribuidor. ${ }^{55}$

Mclaren chega ao detalhe decisivo: a dimensão múltipla da autoria no projeto de um profissional do ilusionismo como Méliès. $\bigcirc$ mesmo pode ser dito de Valerio, ao mesmo tempo fotógrafo, músico, ator em suas próprias imagens, inventor, montador e distribuidor. $\bigcirc$ folheto "O Record Mudial da Photographia" também ressalta esse aspecto na feitura das imagens panorâmicas de São Paulo. Valerio teria atuado em diversas frentes para tornar viável a panorâmica de 1922, desde a concepção de uma captura de cinco chapas sucessivas, a escolha do local, passando pelo desenvolvimento da emulsão do papel, sua fabricação, a ampliação das imagens em um único conjunto e o retoque com tinta à óleo - tudo isso tendo em vista que a obra final tem $16 \times 2$ metros de extensão. A combinação entre trabalho intelectual e artesanal fica clara em todos esses casos.

Há ainda outros exemplos, para além de Méliès, que apontam para um período do cinema, em seus primórdios, anterior ao estabelecimento do repertório clássico de regras do cinema narrativo ficcional, em que imperava tal abordagem mágica da imagem-movimento. ${ }^{56}$ Outros realizadores seguiram os passos abertos por Méliès, desenvolvendo temáticas e ideias em filmes mais longos e sofisticados. Esse conjunto de filmes do chamado "primeiro cinema" só recentemente começou a ser resgatado, revelando intensa utilização de manipulação fotográfica ligada a uma série de histórias fantásticas. Em 1907, o catalão Segundo de Chomón (1871-1929), representante da Pathé em Barcelona, realiza An avant la musique, filme de trucagem que explora de maneira extremamente criativa os aspectos visuais relacionados à música. Estão ali as cabeças dos músicos jogadas ao alto, para formar a partitura, a batuta, o personagem que rege, as linhas e notas musicais. A violação das "regras" da perspectiva linear é realizada em prol da imaginação, da inventividade e da sinestesia. ${ }^{57}$

Émile Cohl (1857-1938), considerado inventor do cinema de animação, também realizou seus experimentos cinematográficos conjugados ao campo da música. Em La Musicomanie (1910), ele apresenta uma dupla de músicos loucos, cuja peça executada propicia uma série de transmutações. $\bigcirc$ filme, como a maioria das produções de Cohl, mistura imagens filmadas com imagens desenhadas, cuja intervenção serve para transportar o espectador a um mundo fantástico, em que tudo é possível. ${ }^{58}$ Cohl também trabalhou a questão da expressividade do rosto e da inserção do corpo humano em ambientes decorativos artificiais. Cadres Fleuris (1910) é um exemplo eloquente dessa técnica. O corpo 
manipulável, que pode ser decomposto, o corpo sujeito a uma série de operações, fatiado, esquartejado, o corpo maleável, já está posto em todos os desdobramentos da manipulação fotográfica e também nos filmes de trucagem do primeiro cinema e vai se desenvolver nas peripécias do cinema burlesco. ${ }^{59}$

$\bigcirc$ truque da multiplicação de um personagem em todos os integrantes de um grupo musical seria retomado no cinema por Buster Keaton (1895-1966), em 1921, quando realiza The playhouse. Assim como Valerio, Keaton se multiplica para além dos integrantes da banda, compondo também personagens da plateia. Keaton é para o burlesco um pouco o que Méliès é para o cinema de atrações. Seus filmes ajudam a consolidar o estilo que conhece o apogeu na década de 1920. The playhouse é já um filme bastante diferente de L'homme orchestre, embora parta de um mesmo princípio. A ênfase no personagem principal, aquele que assume todos os papéis e que, coincidentemente é também o realizador do filme, permanece a mesma. Nesse ponto Valerio, Méliès e Keaton estão "de acordo". A expressividade do gesto que esbarra constantemente no exagero sobretudo da expressão facial do autor-ator - é elemento central na obra dos três. ${ }^{60}$ Porém, o cinema de Keaton se distancia daquele realizado por Méliès na medida em que incorpora a decupagem em planos, atingindo uma narratividade muito mais marcada. The playhouse tem 20 minutos, enquanto L'homme orchestre se reduz a um décimo disso. Em Keaton, o personagem se multiplica também por meio da multiplicação das tomadas. $\bigcirc$ corte e a montagem, aliados à utilização dos intertítulos, permitem a Keaton desdobrar sua atuação ao longo de diferentes enquadramentos e ações, que, encadeados, criam uma história. Além disso, sua abordagem é mais histriônica, mais abertamente voltada ao humor e aos exageros, às elasticidades do corpo fílmico. Ele incorpora a dança e a maquiagem como elementos cruciais. Méliès é mágico, Keaton é comediante.

lance da multiplicação é apenas um dos "números" incluídos em The playhouse. A passagem se revela um sonho, do qual acorda o protagonista chacoalhado por seu patrão. ${ }^{61}$ As paredes do estúdio estão sempre a cair, revelando algo por trás da fachada, o sonho dentro do sonho. $\bigcirc$ cenário se desfaz e se refaz em um passe de mágica, provocando saltos entre os "números" cujo fio condutor é o próprio Buster Keaton, que sempre "escapa" de um cenário a outro. ${ }^{62}$

As duas panorâmicas de São Paulo de Valério Vieira aproximam-se de obras do cinema de vanguarda dos anos 1920, cuja temática gira em torno da grande cidade, a metrópole. Esse tipo de criação fílmica surgiv em diversas partes na mesma época, configurando um movimento histórico e sincrônico bastante peculiar. ${ }^{63}$ A primeira das "sinfonias da metrópole" é Manhatta (1921), de Charles Sheller e Paul Strand. Ali, a grande cidade é exaltada por sua imensidão. Surge guinte: "que pertence ao mundo das fadas, ou é próprio de fadas; mágico, maravilhoso, deslumbrante" [grifos nossos]. Boa parte da produção do chamado "primeiro cinema" não estava ligada ao universo narrativo-literário que iria prevalecer, mas justamente a esse universo mágico maravilhoso do feérico. Muitos filmes foram, inclusive, coloridos à mão, para conferir maior impacto visual. Para se ter uma boa ideia dessa vertente do primeiro cinema, recomenda-se o DVD The fairytales: early colour stencil films from Pathé, compilado pelo British Film Institute em 2012.

55. McLaren (2008, p. 4).

56. Sobre o baixo teor de narratividade nos filmes de Méliès e de outras produções de sua época, Tom Gunning comenta. "O filme de trucagem, talvez o gênero de não-ficção dominante antes de 1906, é uma série de números de atrações mágicas, mais do que um primitivo rascunho de continuidade narrativa" (Gunning citado por Strauven, 2006, p. 384). O "primeiro cinema" ou "early cinema" foi tema de profundas discussões e análises a partir do final dos anos 1970. André Gaudreault questiona a expressão, destacando que os filmes realizados nesse período são de tal maneira distintos do cinema narrativo que se torna hegemônico posteriormente que não podem ser chamados de cinema, estão mais próximos de espetáculos de teatro com uso de fotografias animadas. Gaudreault (2008, p. 9-20).

57. Segundo de Chomón é um criador extremamente original, resgatado há pouco tempo pela historiografia do cinema. Atuando para a Pathé Frères em Barcelona e depois em Paris, Chomón desenvolveu as 
propostas de Méliès, experimentando com todo o tipo de trucagem para construir um cinema voltado ao fantástico. Chomón trabalhou intensamente com colorização, ampliando a paleta de recursos visuais. Cf. livro Segundo de Chomón: un pionnier méconnu du cinéma européen, de JuanGabriel Tharrats (2009).

58. Émile Cohl é também chamado de cineasta incoerente, por conta da falta de sentido lógico de alguns de seus filmes, cuja trama se dá na pura transformação dos objetos, baseada em uma fusão surpreendente de imagens filmadas e desenhos. Cf. obra Émile Cohl, coletânea de textos, imagens e documentos coordenada por Pascal Vimenet (2008).

59. "O cinema burlesco nos ensina, de diversas formas, que o corpo que ele produz é um corpo sempre imerso. Não habitável, mas incopiável, de saída porque ele já está molhado. Ou obsceno, ou seja, inimitável." (Schefer: 2009, 31). Ao escrever sobre o cinema dos anos 1920, Méliès critica profundamente tanto essa maleabilidade do corpo burlesco como as experimentações do cinema de vanguarda, marcando clara distinção para a forma como ele fazia uso do cinema nas suas "féeries". Cf. Gaudreault (2014, p. 41).

60. Em relação à expressividade do rosto, Keaton a utiliza "ao revés", mantendo-o impassível diante do mundo que cai ao redor (Cf. Mongin, 1995, p. 13-14). Em De Charcot à Charlot, Rae Beth Gordon (2013) desenvolve uma instigante tese, na qual defende que a expressividade do rosto burlesco guarda relações com os estudos sobre histeria e outros casos psiquiátricos documentados por fotografias no final do século já um elemento que está excluído das imagens panorâmicas de Valerio: as massas. A multidão é uma das temáticas mais recorrentes da metrópole. A São Paulo de 1922 registrada por Valerio ainda não remete a uma metrópole, pois não se dirige ao seu centro, mas aos arrabaldes. Dela estão excluídas as massas de trabalhadores que se dirigem às fábricas. Ali estão presentes somente as chaminés. A cidade industrial é apenas pressentida detrás das casas, no interior das fachadas.

Ao longo da década de 1920, são inúmeros os filmes que aparecem tendo como mote a cidade e que irão ficar marcados na história do cinema de vanguarda. Em uma verve mais poética, podemos citar Rien que les heures (1926), de Alberto Cavalcanti, De Brug (1928) e Regen (1929), de Joris Ivens, À propos de Nice (1930), de Jean Vigo. Em Paris qui dort (1924), Réné Clair introduz o fantástico em sua leitura da cidade, imaginando a história de um cientista que desenvolve uma máquina capaz de congelar o movimento dos seres humanos. Na Alemanha, surgem alguns clássicos ao longo da década. Em 1927, Fritz Lang concebe Metropolis, ficção científica de perfil distópico que imagina a vida em uma grande cidade no futuro, prenunciando de certa forma o ideal da Germania, a cidade que Hitler ambicionava construir como centro do Reich nazista. ${ }^{64}$ No mesmo ano surge Berlin, Die Sinfonie der Großstadt, de Walter Ruttman, que coloca acento sobre a relação entre a multidão e as máquinas, sobretudo os meios de transporte modernos. Os ritmos da cidade são catalisados pelas máquinas, dentre as quais, a máquina de filmar é mais uma, o filme se aproxima da música pelo formato sinfônico. ${ }^{65}$ Dois anos depois é realizado Menschen am Sontag, de Edgard Ulmer e Robert Siodmak, experimento de filme "sem atores", filmado com "pessoas reais" escolhidas dentre os moradores de Berlim, que mostra a grande cidade em um típico dia de sábado. 66

A República de Weimar foi uma importante usina de ideias e discussões acerca do moderno e da modernidade. Os movimentos de vanguarda na arte foram acompanhados pela formação de uma massa crítica em torno de pensadores da Escola de Frankfurt: Walter Benjamin, Siegfried Kracaver, Georg Simmel, Theodor Adorno e Max Horkeimer. Para além de seu intenso uso pelas vanguardas artísticas, o cinema e a fotografia foram vistos como mídias essenciais para forjar uma arte revolucionária. ${ }^{67}$ É nesse mesmo contexto que surge a fotomontagem dada, cuja configuração é extremamente distinta das fotomontagens de Valério Vieira. ${ }^{68}$

Em O homem da câmera de filmar (1929), Dziga Vertov leva às últimas consequências o experimento de expor a dinâmica da cidade por meio da dinâmica cinematográfica. Ele busca liberar as potencialidades do aparelho, para que possa revelar novas formas de ver. Mostra ao público o próprio aparato, a câmera de filmar, o operador, que é tomado como principal personagem. Desce aos detalhes de como o filme é concebido na mesa de montagem, até chegar ao 
fotograma, unidade mínima e estática. Mostra o dispositivo de exibição do filme: a sala de cinema. Vertov faz uso constante de trucagens como sobreposição de imagens e duplicação. Assim, concebe a cidade como artifício, resultado de agenciamentos maquínicos, entre a subjetividade criativa humana e a capacidade projetiva das máquinas, incluso o cinema, fantástica máquina de visão. ${ }^{69}$

São Paulo também teve sua Symphonia da metrópole (1929), filme dirigido pelos imigrantes húngaros Adalberto Kemeny e Rudolf Lustig. ${ }^{70}$ Colocados lado a lado, - Segundo panorama de São Paulo (1922) e o filme, realizado sete anos depois, criam uma relação de complementaridade e de contraposição. Valerio mostra a cidade desde o centro em direção à periferia, uma cidade cujo vetor é a industrialização, o progresso, visto como ordem. Tudo parece estar em seu devido lugar. $\bigcirc$ artista se expressa por meio de uma única e massiva imagem, resultado da fusão de cinco fotografias cujas emendas não são percebidas. Sua panorâmica é concebida como ideal de imersão no espaço expositivo, representação da grandiosidade da paisagem urbana por meio de uma imagem igualmente grandiosa, hiperbólica. Kemeny e Lustig, ao contrário, optam por mergulhar no centro comercial e financeiro da cidade, mostrando de perto o movimento das pessoas e dos bondes, do dinheiro e das mercadorias. Trata-se de uma obra cujo vetor é a circulação. Existem ali planos amplos que englobam a paisagem urbana de maneira geral, porém voltados ao Vale do Anhangabaú, ponto nevrálgico e central. A figura humana salta a todo momento ao primeiro plano. É preciso observar que, acima de tudo, há uma diferença entre os recursos disponíveis nas duas mídias, que condiciona as restriç̃ẽes de lado a lado. $\bigcirc$ cinema, por meio da montagem, permite encadear planos-sequência de duração, movimento e amplitude variáveis, modulando ritmos e intensidades. A fotografia é um molde estático, cujo processo de fragmentação e montagem depende mais da observação ativa do espectador. ${ }^{71}$ É ele quem, no ato de contemplar uma fotografia, reenquadra e percorre suas linhas de força, pontos de fuga e de atenção. Dois tipos distintos de montagem que emergem com a modernidade: a panorâmica de Valerio é totalizante, enquanto o filme de Kemeny e Lustig atua por meio da fragmentação, estando mais próximo da abordagem das vanguardas do modernismo.

\section{TEATRO, TRANSFORMISMO E INCORPORAÇÃO}

Dentre as imagens publicadas no livro The pencil of nature, do pioneiro Henry Fox Talbot (1800-1877), há uma bastante prosaica, intitulada The ladder (A escada). Esse é de fato o elemento central da composição, mas Talbot não quer
XIX. Petr Kràl nota a proeminência da promoção da própria imagem nos realizadores do cinema burlesco. "Exatamente como os dandys, por sinal, os cômicos vivem uma irremediável solidão num mundo cada vez mais 'coisificado' (apesar de seu desejo de uma dispersão cósmica). Quando Keaton, no começo de The Playbouse, encarna sozinho todos os atores e espectadores de um programa de variedades, é também a imagem de uma fatal enclausura do Eu em si mesmo”. Kràl (2007, p. 130).

61. "Um dos filmes mais ricos de Keaton é sem dúvida o mais insólito, o mais onírico, o mais surrealista. $\mathrm{Na}$ primeira parte, a ideia de saída é rigorosamente desenvolvida e o desafio estritamente realizado: Keaton executa todos os papéis. Ainda que descritas inúmeras vezes, essas cenas guardam intacto todo seu poder de fascinação." Coursodon (1973, p. 76).

62. "Um corpo manipulado sem cessar pelo tempo fílmico; em todos os roteiros, pois ele está sempre atrasado em seu desenrolar, porque o mundo se enlouquece ao seu redor: se desmorona, transborda e se põe a correr." Schefer (2009, p. 31).

63. Peter Weiss dedica um capítulo especialmente à cidade no clássico livro $\mathrm{Ci}$ néma d'avant-garde. Cf. Weiss (1988, p. 99-109). Ricardo Mendes indica a proximidade do Segundo Panorama de São Paulo com o cinema, apesar de sua matriz pictórica oitocentista. "Críticas podem ser apontadas no fato desta obra estar muito próxima de uma produção fotopictorialista, com recursos de intervenção sobre a imagem fotográfica, realçando detalhes, corrigindo perdas de dados no processo de ampliação, mas é essa ima- 
gem em grande escala, próxima tanto da arte mural como do nascente cinema, o aspecto mais importante de seu gesto, posicionando a fotografia num segmento ocupado pelos suportes consagrados." Mendes (2003, p. 1).

64. Siegfried Kracauer aponta a proximidade entre os elementos apresentados em Metropolis e os posteriores desdobramentos políticos na Alemanha, com a tomada de poder pelos nazistas. Kracauer (2004, p. 162-164).

65. "Seu senso de música ótica fez com que Ruttmann parecesse o homem certo para produzir uma 'melodia de imagens'. Ele trabalhou em colaboração com o jovem compositor Edmund Meisel, conhecido por sua interessante trilha para Potemkin. Meisel sonhava em sincronizar a sinfonia visual de Ruttmann com uma composição sinfônica que poderia até mesmo ser executada de forma independente do filme. O papel reservado à música estava pronto a fortalecer a tendência formal da edição." Kracauer (2004, p. 183).

66. Raymond Bellour inscreve Menschen am Sontag na tradição dos "filmes de cidades", porém com significativas diferenças para a abordagem de Ruttman. "É a cidade que é festejada, a Berlim agitada evocada por tantos escritores e artistas, em sua modernidade, sua simultaneidade, suas velocidades, em todos os meios de locomoção misturados que são emblema. Mas também sem excessos, bem longe da exaltação sistemática de um Ruttman." Bellour (2009, p. 23).

67. A exposição Film und Foto, realizada em 1929, que passou por diversas cidades da Alemanha e por outros países, se destacou por trazer fotografia e cinema juntos a um mesmo es- se referir à escada quando apresenta a imagem. Seu comentário se dirige às pessoas que posam tendo como uma espécie de pilar a escada. Dois dos homens, um de frente e outro de perfil, estão literalmente apoiados na escada, enquanto o terceiro elemento, de costas, apoia-se indiretamente, por meio de um olhar fixo lançado ao objeto. A cena foi obviamente concebida, embora não haja nela nenhuma complexidade cênica. Talbot jogou com os elementos que tinha à mão. Em seu comentário sobre a imagem, ele escreve.

Retratos de pessoas vivas e grupos de figuras formam um dos mais atrativos temas [subjects] da fotografia [...]. Se nos dirigimos à cidade e tentamos fazer uma foto da multidão movente, não obteremos sucesso, pois em uma pequena fração de segundo as pessoas mudam de posição, o que destrói a nitidez da representação. Mas quando um grupo de pessoas é artisticamente posicionado e treinado com um pouco de prática para manter-se em absoluto imobilismo por alguns segundos, imagens agradáveis podem ser obtidas facilmente. ${ }^{72}$

Talbot foi extremamente honesto com seu leitor. Ele revela que seu invento ainda tem limitações inerentes com relação ao tempo exigido para a pose, o que impediria de registrar uma multidão movente. Porém, diante de um exercício de prática para manter a absoluta imobilidade pode-se chegar a resultados satisfatórios, registrando para sempre os raios de luz refletidos por um ente querido em uma imagem nítida, uma recordação autêntica. $\bigcirc$ "lápis da natureza" regista os traços de maneira fidedigna, mas para que tal ocorra é preciso haver um ato consciente de representação. Fotógrafo e fotografado representam um papel, tendo em vista as regras do jogo. Na época de Talbot, tais regras ainda previam que era necessário permanecer imóvel por um longo período de tempo. As regras são flexíveis, mudam conforme a tecnologia avança, trazendo novas condições materiais.

A famosa vista do Boulevard du temple, tomada em algum momento entre os dias 24 de abril e 4 de maio de 1838, para mostrar ao mundo o invento de Louis Daguerre (1787-1851), deve ter de fato causado impacto quando foi mirada pela primeira vez. A enorme nitidez desse novo tipo de imagem, em cuja feitura a mão humana não intervém, assusta. ${ }^{73}$ Mas ao observador da época deve ter causado espanto sobretudo seu aspecto espectral: onde estavam as pessoas? $\bigcirc$ Boulevard du temple era uma das principais artérias de Paris, extremamente frequentada. Os contornos dos prédios estão nítidos, mas não se vê ninguém de humano. Exceto pelos dois personagens posicionados no canto direito do clichê, em sua versão não invertida. A legenda da imagem fornecida pela Wikipedia em francês poderia nos ajudar na leitura de uma imagem tão inusual. 
Daguerreótipo. Trata-se provavelmente da primeira fotografia de uma pessoa viva. Ela representa acima de tudo uma rua movimentada. Durante o tempo de exposição, que passou de 10 minutos, o tráfego se mostrou muito rápido para ser registrado. Somente aparece o homem abaixo à esquerda, que restou imóvel durante o tempo em que tinha seus sapatos engraxados. Como todo daguerreótipo, a imagem está invertida lateralmente. ${ }^{74}$

Daguerre nos faz pensar (até hoje) que teria sido o acaso que fez com que o senhor parasse, por cerca de 10 minutos, para encerar seu sapato, em somente um dos pés e que o zeloso engraxate teria se movido tão pouco. Mas, e se Daguerre solicitou a alguém que assumisse tal papelę75 Essa hipótese é no mínimo plausível, já que ele precisava demonstrar que seu invento era capaz de registrar o principal assunto, aquele que Talbot já nomeara como prioritário, os seres humanos, em todas as suas feições. Por mais que a multidão não esteja representada, dado seu incessante deslocamento, aqueles dois personagens estão ali para assegurar que a fotografia tem uma escala humana, uma dimensão pessoal. A questão do quanto uma cena pode ser encenada ou não, para a fotografia instantânea, deixa de ter sentido na medida em que nos leva a becos sem saída. Não existe fronteira possível entre o espontâneo e o posado. Todo instantâneo carrega consigo certa dose de ficção. ${ }^{76}$ Um ditado famoso que explica tal paradoxo nos adverte que "as fotografias não mentem, mas os fotógrafos sim". Julgar se uma fotografia foi ou não manipulada é exercício para quem reflete acerca de questões éticas e não estéticas.

Sabemos todos que a vaidade humana é capaz de mover montanhas. $\bigcirc$ ato oficial de "invenção" da fotografia por Daguerre, sacramentado pelo discurso de François Arago, deixou um rastro de desafetos, egos contrariados pelo não reconhecimento como pais legítimos da maravilhosa tecnologia. Hippolyte Bayard (1801-1887) é um desses. Para se "vingar" e chamar a atenção da opinião pública, faz um jogo de cena engenhoso, um autorretrato "afogado", debitando a culpa de seu "suicídio" na falta de reconhecimento do governo francês por sua contribuição para o invento. Ao fotografar-se, Bayard também dava provas, de quebra, de seu domínio da técnica. A imagem não comprova sua morte, uma jogada de ficção, mas comprova o seu invento. No verso da imagem, ele escreve a seguinte explicação:

O cadáver que vocês veem aqui é do Sr. Bayard, inventor do procedimento que vocês acabam de ver ou cujos maravilhosos resultados vocês irão ver. Pelo que sei, há cerca de três anos que esse engenheiro e infatigável pesquisador se ocupava de aperfeiçoar seu invento.

A Academia, o Rei e todos aqueles que viram esses desenhos, que os achavam imperfeitos, os admiraram como vocês os admiram neste momento. Isso o honra sobremaneira e não valeu a ele nenhum tostão. O governo, que havia dado demais já ao Sr. Daguerre disse que nada poderia fazer pelo Sr. Bayard e o infeliz se afogou. Oh! instabilidade das coisas humanas! Os paço expositivo, reunindo trabalhos de todas as vertentes da vanguarda europeia. A obra de Moholy-Nagy (2007) é referencial nesse contexto.

68. Sobre a fotocolagem dada, cf. obra clássica de Hans Richter (1997).

69. O construtivismo russo também teve na fotomontagem um de seus principais meios expressivos, praticados por artistas como Alexander Rodchenko, El Lissytsk e Gustav Klucis.

70. "Rodolf Lustig e Adalberto Kemeny eram húngaros e já faziam cinema desde os 17 anos de idade. Depois da primeira guerra foram para Berlim trabalhar em estúdios cinematográficos alemães. Em 1922, Rodolfo veio para o Brasil e em 1926, já diretor técnico da Independência Filmes em São Paulo, de Armando Pamplona, mandou buscar Adalberto na Alemanha. Em 1928 compraram o prédio e o acervo da produtora e fundaram a Rex Filmes." Altafini (1999, p. 8).

71. "O plano é um corte móvel, quer dizer, uma perspectiva temporal ou uma modulação. A diferença entre a imagem cinematográfica e a imagem fotográfica decorre disso. A fotografia é uma espécie de 'moldagem'; o molde organiza as forças internas da coisa de tal modo que elas atingem um estado de equilíbrio num certo instante (corte imóvel). Enquanto a modulação não se detém quando o equilíbrio é atingido, e não pára de modificar o molde, de constituir um molde variável, contínuo, temporal.” Deleuze (1985, p. 37).

72. PLATE XIV. The pencil of nature, Henry Fox Talbot (2010, p. 41) 
73. Niecephore Nièpce já havia desenvolvido um método para a fixação da imagem na superfície fotossensível, utilizando betume da judeia para obter a primeira imagem fotográfica de que se tem notícia até hoje, tomada da janela de seu estúdio, em 1827. Após a morte prematura de Nièpce, Daguerre dá continuidade aos estudos até a invenção do daguerreótipo, oficialmente anunciado em 1839. A grande diferença da imagem que Daguerre obteve, para além dos suportes fotossensíveis completamente distintos, está na nitidez. É essa fartura de detalhes que assusta na imagem fotográfica, associada à extrema rapidez com que ela "se realiza": mesmo que a fotografia de Daguerre tenha sido feita ao longo de uma dezena de minutos, imagine quanto tempo levaria a concepção de um desenho com tamanha riqueza de detalhes.

74. Wikipedia (consultado em 8 de agosto de 2016).

75. Esse é justamente o mote para o livro El limpiabotas de daguerre, de Antonio Ansón (2007).

76. Sobre a relação entre fotografia e ficção, cf. Pbotography as fiction, de Erin Garcia (2010). Não podemos deixar de mencionar os estudos de Boris Kossoy sobre a fotografia, buscando entender o seu estatuto ambíguo de documento e porta de entrada para a ficção. Cf. Kossoy (1999; 2001).

77. Citado a partir da coleção Photo Poche em seu número 91, dedicado a Hippolyte Bayard (2001). A publicação não tem números de página. A foto correspondente é numerada 21. Bayard (2001, s.n.).

78. Em Burning with desire, Geoffrey Batchen (1999) realiza um original artistas, os sábios, os jornais se ocupam dele há muito tempo e hoje, que há vários dias ele está deposto em uma câmara mortuária, ninguém ainda o reconheceu ou deu por sua falta. Senhores e Senhoras, passemos a outros assuntos, com receio de que seu olfato não seja afetado, pois o rosto do Senhor e suas mãos começam a apodrecer, como vocês podem perceber.

H. Bayard. 18 de Outubro, 1840.77

Tal imagem parece "afogada" pela história. Seus contornos diluídos criam uma textura etérea. Um inevitável acúmulo de tempo se deu em sua superfície. Ainda assim, seguindo as indicações do fotógrafo, podemos deduzir pelas mãos, escurecidas, o estado de putrefação do cadáver. São as mãos que manipularam os fatos e as mãos que manipularam os instrumentos que cercam o invento. ${ }^{78}$

Todos esses exemplos, que remontam aos primórdios da fotografia, nos conduzem a uma condição que está dada desde o início: o retrato como espaço cênico construído. A manipulação dos dados factuais já está colocada desde o princípio, como "pecado original" da fotografia. Para além dos elementos cênicos ou encenados, existe toda uma fenomenologia da pose, que Barthes desenvolveu sobremaneira no ensaio "A Câmara Clara". 79 Todo retrato, ou quase todo, pois existem também os retratos "roubados", é resultado de uma interação, pressupõe uma certa conivência ou uma não aceitação. Ser fotografado é ritual místico que toca fundo. A fotografia é ato cênico na medida em que opera um encontro de subjetividades, em que propicia uma troca de olhares. ${ }^{80} \mathrm{~A}$ fotografia traz consigo essa obsessiva capacidade de fixar um olhar. Então, ela já saiu há tempos do plano puramente factual e habita indistintamente o plano da teatralização.

$O$ retrato foi a primeira atividade de grandes dimensões comerciais para a fotografia, seu primeiro grande gênero. ${ }^{81}$ Os estúdios do século XIX eram verdadeiros teatros da vaidade, nos quais se lançava mão de recursos cênicos, compostos por fundos, mobiliário e cenografia. Por trás de todo grande retratista há, quase sempre, um grande cenógrafo e um profissional da imagem que domina a arte da direção, que passa sempre pela comunicação interpessoal. ${ }^{82} \mathrm{~A}$ construção cênica de Os trinta Valérios é de enorme complexidade, envolvendo a construção de um espaço interno que é captado desde um ponto de vista ligeiramente elevado, conferindo maior profundidade. A cena está iluminada de maneira uniforme. As roupas e objetos são criteriosamente escolhidos. $\bigcirc$ traje de gala é o dress code do evento festivo, indicando que pode tratar-se de algo mais refinado do que um sarau. Os músicos e convidados estão impecavelmente vestidos com smoking e gravata borboleta. O garçom, o mestre de cerimônias e o fotógrafo se distinguem dos demais por detalhes da vestimenta. É interessante observar como Valerio representa os diversos papéis, buscando fazer surgir diferentes facetas de sua 
personalidade nos diferentes personagens da cena. Uma planta orna o fundo da sala e um dos quadros tem uma coroa de flores ao redor. $\bigcirc$ cômodo tem um papel de parede que atesta seu emprego para ocasiões nobres, muito provavelmente trata-se de um estúdio fotográfico, dado o recuo que se consegue obter, mostrando uma cena ampla que se realiza em ambiente interno. Os detalhes de decoração na parede onde se encontram os quadros faz lembrar de uma das fotografias que mostram a exposição de Valerio no Salão Progredior, em 1905.

Para além das proximidades entre o estúdio fotográfico e o teatro, a inspiração para a criação de Os trinta Valérios parece ter vindo de um espetáculo teatral. Em notícia do jornal $\bigcirc$ Commercio de São Paulo recolhida por Boris Kossoy, publicada em 9 de março de 1902, conta-se da reabertura do "acreditado ateliê" Photographia Valerio, do artista Valério Vieira, em São Paulo. ${ }^{83}$ Dentre as obras expostas, que passavam pelas mais variadas técnicas em voga, Valerio apresentou ao público o quadro Valerio Fregoli. Provavelmente esse tenha sido o título original concebido por seu autor para Os trinta Valérios. Mas quem foi Fregolię Valerio sem dúvida faz menção ao humorista italiano Leopoldo Fregoli (1867-1936), cujo nome hoje caiu no esquecimento, mas à época fazia enorme sucesso em Paris com um número no qual se travestia de diversos personagens, trocando de roupas, encarnando os trejeitos, a voz e sua entonação. Uma deliciosa biografia desse "monstro do teatro" no fin de siècle, escrita por Jean Nohain e François Caradec, deixa-nos entrever inúmeras correspondências que unem os dois personagens - Fregoli e Valerio. ${ }^{84}$

Em 1900, Fregoli alcança um feito. Ele realiza 300 apresentações consecutivas no Olympia, sozinho. Ele é um one man show, maior atração do music hall parisiense. ${ }^{85}$ Salta de papel em papel, é capaz de se travestir em um piscar de olhos. Se exprime perfeitamente em italiano, francês e inglês. Faz paródias de óperas, passando por Rossinni, Donizetti, Verdi, Wagner, Meyerbeer, Mascagni, Gounod, Bizet... incorpora Tristão, Gismonda, Canis, Lohengrin, Hernani, Mefistófeles, Rigoletto... se traveste de mulher, de marido e amante, de júri, julgado e juiz. Uma pequena coletânea de frases publicadas nos jornais parisienses permite perceber a extensão o fenômeno Fregoli.

É simplesmente o artista mais proteiforme o mais impressionante que existe. (Henri Rochefort, L'Intansigean)

Ventríloquo, mímico, comediante, imitador, músico, ilusionista. é louco, é alucinante e no entanto ele existe e se chama Fregoli. (Crispin, Le Journal)

Fregoli foi além de todos os limites do impressionante. Ele encarna sozinho um teatro todo inteiro! (René Marton, Le Figaro) retorno ao tempo dos pioneiros da fotografia, demonstrando como o invento comporta uma enorme variedade de interpretações e de aplicações desde seu início. Batchen busca apontar para além da dicotomia entre as correntes identificadas por ele como "formalista", que busca uma essência na mídia fotográfica, e "pós-moderna", que entende que a fotografia só pode ser apreendida no contexto social e discursivo em que se insere.

79. “A Foto-retrato é um campo cerrado de forças. Quatro imaginários aí se cruzam, aí se afrontam, aí se deformam. Diante da objetiva, sou ao mesmo tempo: aquele que eu me julgo, aquele que eu gostaria que me julgassem, aquele que o fotógrafo me julga e aquele de que ele se serve para exibir sua arte." Barthes (1980, p. 27).

80. Barthes entende a proximidade entre fotografia e teatro por meio da encenação da morte, o que nos aproxima da representação criada por Bayard. "Não é, porém (parece-me), pela Pintura que a Fotografia tem a ver com a arte, é pelo Teatro. Na origem da Foto, sempre colocamos Nièpce e Daguerre (mesmo que o segundo tenha usurpado um pouco o lugar do primeiro); ora, Daguerre, quando se apossou da invenção de Nièpce, explorava na praça do Château (na République) um teatro de panoramas animados por movimentos e jogos de luz. A camara obscura, em suma deu ao mesmo tempo o quadro perspectivo, a Fotografia e o Diorama, sendo todos os três artes da cena. Mas se a Foto me parece mais próxima do Teatro, isso ocorre através de um revezamento singular (talvez eu seja o único a vê-lo): a Morte." Barthes (1980, p. 52-53). 
81 O livro de Gisèle Freund, Photographie et société, descreve esse fenômeno em detalhes, demonstrando como a demanda pelo retrato estava ligada à emergência de uma classe média que acedia aos bens de consumo antes reservados à burguesia. "O desenvolvimento do retrato fotográfico corresponde a uma importante fase de desenvolvimento social da Europa Ocidental: a emergência das classes médias que, pela primeira vez, garante poder político e econômico a amplos segmentos da população. Para responder à demanda por mercadorias, quase tudo tinha que ser produzido em grandes quantidades. O retrato não era exceção: ter um retrato significava às classes em ascensão a afirmação de seu novo status social, tanto para si mesmos como para o mundo. Para atender à demanda de retratos, a arte se tornou mais e mais mecanizada. $\mathrm{O}$ retrato fotográfico era o estágio final nesse caminho em direção à mecanização." Freund (1980, p. 9).

82. Quando morava em Ouro Preto, Valério Vieira foi amigo do francês Emílio Rouède, com quem teria aprendido muito sobre artes cênicas. "Valério foi atuante na vida social de Ouro Preto e, apesar de continuar aperfeiçoando-se na arte do retrato, realizava trabalhos profissionais para grupos ligados ao governo e também para o jornal Gazeta de Ouro Preto. Neste círculo social conheceu Emilio Rouéde, pintor, escultor, dramaturgo, jornalista e músico francês, que chegou ao país em 1880. Tornou-se grande amigo de Rouéde com quem aprendeu muito sobre artes cênicas”. Balady (2012, p. 44).

83. "Photographia Valerio; Reabriu hontem o seu acreditado atelier a Rua Quinze de Novembro n. 19, o artista Valerio, que tem revolu-
Fregoli, é o gênio da transformação. Se Proteu retornasse e Fregoli o convidasse a um duelo, eu apostaria todas as minhas fichas em Fregoli. Ele é tão velho, Proteu! E Fregoli é tão jovem e tão moderno! (Auguste Gemain, L'Écho de Paris)

Não se sabe dizer como esse diabo de homem encontra o extraordinário poder de se multiplicar, parecendo possuir o dom da ubiquidade reservado até hoje somente aos deuses do Olimpo! (Strapontin, Gil Blas)

A Itália tem quatro glórias das quais ela se orgulha: o tenor Caruso, o poeta Gabrielle D'Annunzio, o inventor Marconi e o 'transformista' Fregoli. Fregoli é certamente o mais original, eu ousaria dizer o mais nacional. (P. de Giusielle, Le Journal des Débats) ${ }^{86}$

Troque Fregoli por Valerio e terá algo muito próximo do efeito causado por Valério Vieira ao apresentar Os trinta Valérios e todas as demais peripécias à sociedade paulista de sua época. Valerio, o fotógrafo, o músico, o ilusionista, o transformista, mímico, comediante, um diabo que tem o dom de se multiplicar, tão jovem e tão moderno. Até mesmo nas origens italianas os dois personagens se aproximam. É claro que a hipótese é um tanto controversa e exagerada, mas tratemos de guardar as proporções.

Como Valerio terá conhecido Fregoli? Certamente em alguma apresentação em Paris, ou então em terras brasileiras. Conta a biografia de Fregoli que ele veio ao Brasil em turnê pela América do Sul realizada justamente na virada do século, em 1899-1900. Quando se apresentava no Rio de Janeiro, ficou bastante conhecido na cidade por conta de uma passagem anedótica. $\bigcirc$ ápice de seu espetáculo era, naquela altura, uma incorporação da danse serpentine, estilo de dança peculiar, criado por Loïe Fuller (1862-1928) e executado por ela mesma mundo afora, tornando-a conhecida por tal performance. A danse serpentine tem uma gestualidade própria; envolve o uso de uma roupa branca com sobras de tecido que são manejadas pela dançarina de forma a criar desenvolvimentos visuais inesperados por meio do incessante movimento dos braços. A dançarina é iluminada com um sistema de luzes coloridas cambiantes. Ao incorporar Loïe Fuller, Fregoli se tornava possuído, em uma paródia cheia de espiritualidade e dotada também de certa ironia mordaz. $\bigcirc$ número era tão bem executado que muitas vezes foi citado como ápice do espetáculo pelos críticos da época. Quando o apresentou na cena carioca, como o sistema elétrico do Teatro Municipal não tinha potência suficiente, apelou-se a uma gambiarra para puxar energia diretamente da linha dos bondes. Todos os dias, na hora da danse serpentine, os bondes entravam em pane. Os passageiros se entreolhavam, comentando: "Ah sim! É Fregoli", ${ }^{87}$

Leopoldo Fregoli também tinha enorme senso de oportunidade e apropriou-se do cinematógrafo para seus espetáculos assim que entrou em contato com a invenção 
dos Irmãos Lumière. Consciente da importância de alimentar o marketing em torno de seu nome artístico, ele tratou logo de rebatizar o invento de "fregoligraph". 88 No catálogo de vistas dos irmãos Lumière existem registros de Leopoldo Fregoli e Loïe Fuller executando a danse serpentine. Ironicamente, o primeiro a executar seu número diante do cinematógrafo recém-inventado foi o parodiador, em 1897. A vista em que a dançarina executa seu número posteriormente foi colorizada à mão e tornou-se referencial para a história do cinema. ${ }^{89}$ Assim como Fregoli incorporava Loïe Fuller, Valerio incorporou Fregoli, executando também seu número de transformismo e multiplicação e utilizando a fotomontagem como ferramenta para registrar e plasmar o teatro de si mesmo diante de sua "plateia" de espectadores.

\section{MÚSICO ANÔNIMO, CÉLEBRE FOTÓGRAFO}

Os trinta Valérios é uma peça de fotomontagem extremamente musical. Em sua dimensão mais evidente, a temática, ela exibe um espetáculo, composto de músicos, plateia e, inclusive, serviçais. Para além disso, há todo um ritmo, uma ginga, um trabalho de modulação espacial dos personagens, que interagem entre si de maneira harmoniosa e dinâmica. A fotografia, por meio da montagem, parece transcender seu caráter de imagem estática e silenciosa. Os trinta Valérios exala melodia. Transpõe-nos a uma festa alegre e sincopada, sob a batuta do multiartista exibicionista.

Se fosse para designar um papel principal, o personagem encarnado pelo próprio artista em Os trinta Valérios, teríamos enormes dificuldades. Será ele o fotógrafo que emerge para conceber a imagem e registrar a cena para a posteridade? Ou aquele que recebe o fotógrafo, estendendo a mão, gesto que se estende a todos nós, espectadores da(e) imagem(ns), convidados a mergulhar em sua densa trama ficcional? Senão, aquele que serve, mais humilde e nobre das funções, o que entrega, como emissário de uma mensagem, o serviçal? Seria a mulher estatueta, único personagem transgênero a habitar a imagem, também o único petrificado, literalmente, que lança um olhar e um sorriso faceiros aos homens que participam da celebração? Seria o regente, que dita a afinação dos músicos com sua varinha de condão, em torno do qual parece tudo orbitar? Ou o cantor, que se expressa em altíssimo e bom som, a plenos pulmões, em incontida verve? Seria, quem sabe, o pianista, cujo timbre e a evolução carregam docilmente o espetáculo em suas mãos? Não há personagem principal. Todos eles dançam incessantemente, como em uma peça de Luigi Pirandello (1 867-1936): personagens em busca de um autor, ou autor que se transmuta em personagens, des-dobrando-se. cionado a photographia ultimamente, apresentando ao público trabalhos de primeira ordem e novos no gênero. Hontem, vimos alli expostos explêndidos processos como sejam a l'Art Nouveau, Phototypia, Aquarellas, Pastel, Pleo, Carvão, Miniaturas, alto relevo, e Geminatura, novidade em São Paulo, isto é: gravação de retratos sobre crystal de espelho. Em miniaturas vimos trabalhos nítidos em cartão, porcellana e marfim, destacando-se na exposição o quadro $\mathrm{Va}$ lerio Fregoli, composto de 30 figuras, e o interessante grupo Fé, Esperança e Caridade. Fizeram-se representar os jornaes da capital. Por ocasião do lauto lunch servido aos convidados foram trocados amistosos brindes e por nossa vez reiteramos as saudações ao distincto artista, agradecendo a gentileza do convite com que honrou esta redação”. Kossoy (2002, p. 319).

84. Falo do livro Fregoli: sa vie et ses secrets, publicado pela editora Jeune Parque. Cf. Nohain; Caradec (1968). Refirome ao artista apenas como Fregoli, sem acento, pois essa era o nome artístico sob o qual Leopoldo Frégoli se apresenta ao público, atitude também assumida por Valério Vieira, que se identificava diante de seu público apenas como Valerio.

85. O nome de Fregoli foi tão famoso à época que resultou em outras apropriações. O título em francês de The playbouse é "Frigo Fregoli", que faz menção direta entre o filme de Buster Keaton e o espetáculo transformista de Fregoli. A psiquiatria cunhou o termo "síndrome de Fregoli" para denominar uma doença que acomete a memória ativa e dificulta o reconhecimento de pessoas familiares, parecendo que elas mudaram de personalidade. "Em 1927, 
Courbon e Fail descreve a Síndrome de Fregoli (SF) nome tomado do ator italiano Leopoldo Fregoli, que era reconhecido por sua habilidade para fazer rápidas mudanças em sua aparência em suas atuações. Caracteriza-se por uma identificação delirante de familiares como estranhos. Em 1932, Courbon e Tusques descrevem a síndrome de itermetamorfose (SIM), que consiste na convicção delirante de que pessoas próximas a ele modificam seu aspecto, mudando-se em outras pessoas." Rodriguez (2008, p. 25).

86. Nohain, Caradec (1968, p. 12-13), grifos nossos.

87. Cf. Nohain, Caradec (1968, p. 52-53).

88. Giovanni Lista aponta a influência dos filmes de Fregoli na vanguarda futurista italiana. "Entre $1898 \mathrm{e}$ 1900, Fregoli realiza seus curtas-metragens trabalhando em duas direções: a subversão da mídia e o filme-performance. Ele experimenta também inovações linguísticas que serão típicas da vanguarda, como a inversão do movimento e a filmagem descontinuada, ao passo que com o filme Fregoli Dietro le Quinte celebra de maneira exemplar os valores futuristas que serão mais tarde reivindicados por Marinetti: a rapidez, a heterogeneidade, a surpresa, a mobilidade psíquica, a presença absoluta do gesto que reduz o ser à sua simples aparência.” Lista (2008, p. 14).

89. No catálogo de vistas Lumière, encontra-se a descrição: "A primeira das duas vistas seguintes, apresentada nos contatos fotográficos, é interpretada por Leopoldo Frégoli, travestido de dançarina. [...] A segunda versão é certamente posterior e parece corresponder melhor à descrição dada no Catálogo de vistas para Cinematógra-

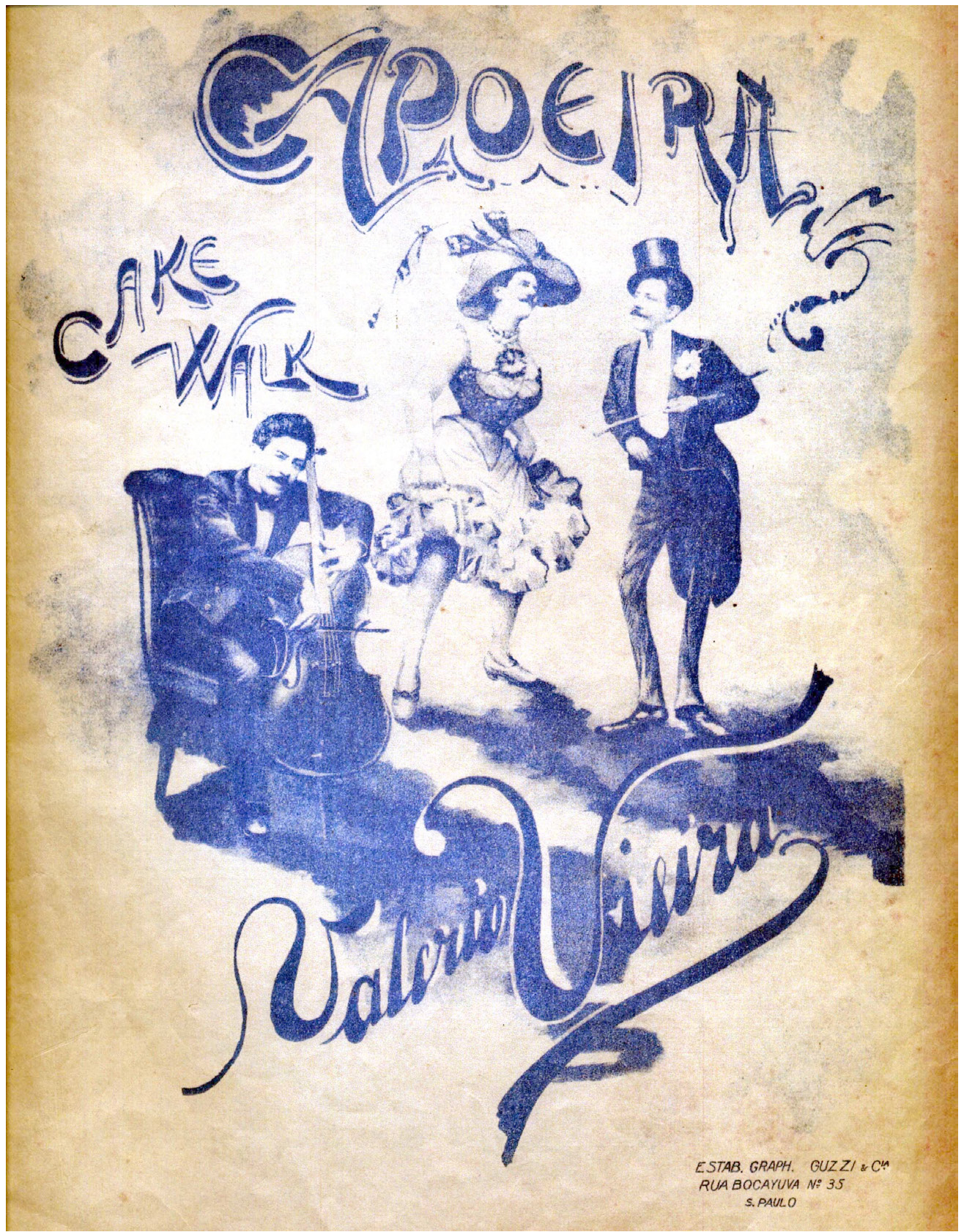

Figura 10 - Capa da partitura de Capoeira (s.d.), uma cakewalk, Valério Vieira. O artista se traveste de músico e no garboso casal que esbanja descontração. Fonte: Acervo Biblioteca Nacional.

Além de fotógrafo e pintor, Valério Vieira era também músico. ${ }^{90}$ Antes de direcionar definitivamente seu ímpeto criativo no sentido das artes plásticas, ele teve fugaz carreira de compositor. A música certamente o acompanhou durante toda a vida, condicionando escolhas estéticas e moldando concepções imagéticas. Os trinta 
Valérios é o exemplo mais acabado dessa fusão de imagemaker com musicmaker, ${ }^{91}$ mas há outros ainda. A capa da partitura de "Capoeira", música em estilo cakewalk, na qual Valerio assume o papel de músico e de um animado casal da alta sociedade antecipa aspectos de "Os Trinta Valérios", mas marca duas diferenças importantes: a presença da dança e o artista que se traveste de mulher em "carne e osso" e traje completo (Figura 10). ${ }^{92}$ Em um retrato presente na coleção de Sonia Balady, Valerio registra uma mulher que posa apoiada em notas musicais, revelando a presença desse tipo de motivo também em retratos comerciais (Figura 11 ).

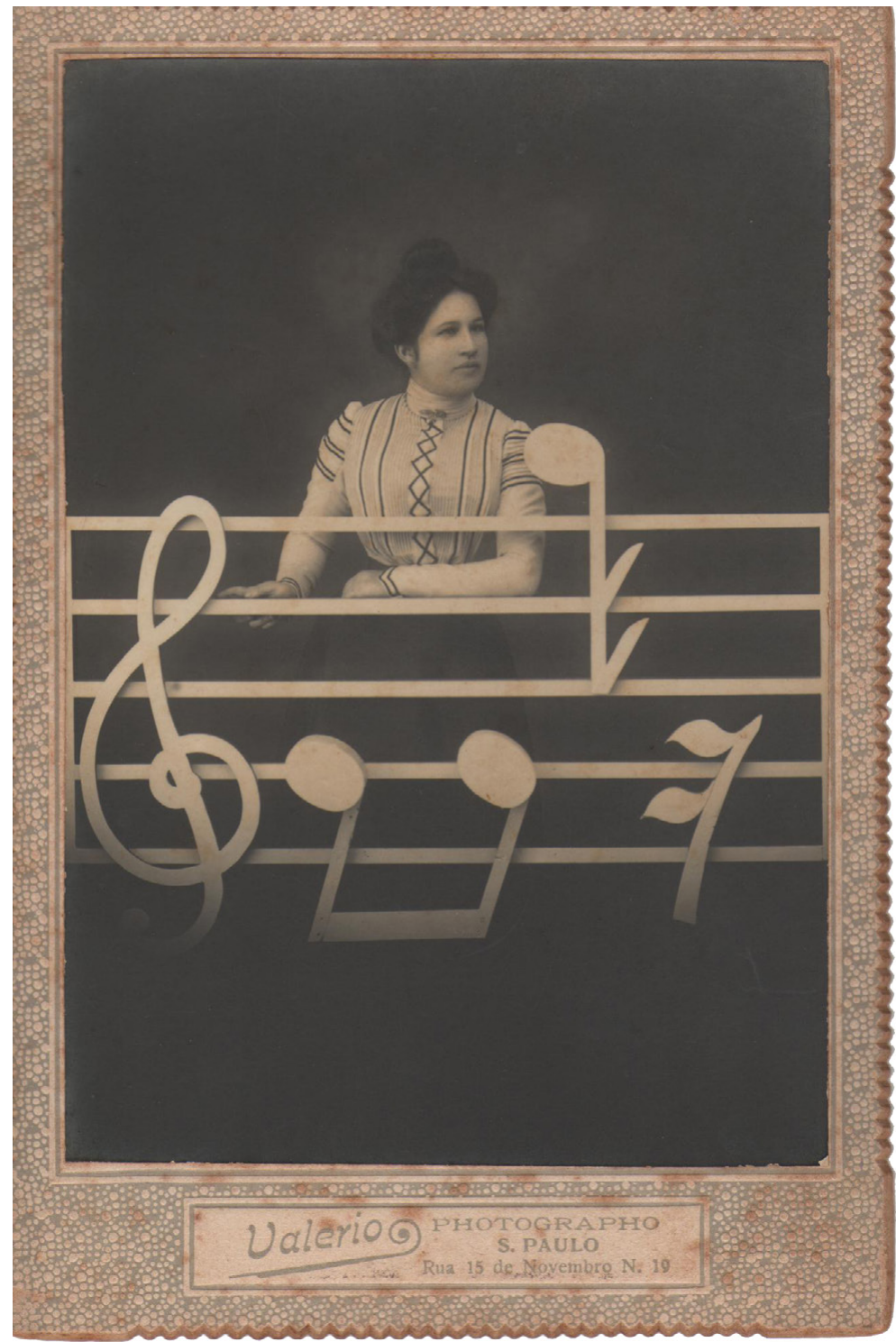

Figura 11 - Retrato de Mulher (s.d.), Valério Vieira. A música como motivo cenográfico adotado no estúdio fotográfico. Fonte: Acervo Sonia Balady. fo de 1905. [...] A danse serpentine, colocada em moda pela dançarina americana, Loïe Fuller, provoca um verdadeiro entusiasmo no espetáculo de music-hall. 'Mulher-flor, Mulher-libélula, Mulher-borboleta...', a dançarina, vestida de uma longa túnica de seda semitransparente, entra em cena no escuro absoluto. Movimentando sua túnica com as duas mãos, ela imprime movimentos giratórios, desenhando espirais e hélices com as extremidades de seu vestido e isso com uma agilidade e uma presteza maravilhosas... No mesmo instante, raios luminosos brotam; recebendo a luz, a dançarina é recoberta por cores múltiplas e cambiantes : 'o efeito multicolor é verdadeiramente mágico'. (La Nature, Paris, n ${ }^{\circ} 1030$, 25 de fevereiro, 1893, p. 205-206). A partir de 1893, Paris inteira se movimenta e são criadas matinées especiais de duas horas e meia para admirar a 'Serpentina', a 'Violeta', ou a 'Borboleta'." Loïe Fuller registra patente de sua dança, mas não consegue impedir a legião de imitadores. A peça foi registrada em inúmeras variantes nos primórdios do cinema. Disponível em: $<$ https://bit.ly/3rkBEmn>.

90. "As partituras de Valério Vieira eram publicadas por Buschmann \& Guimarães, no Rio de Janeiro, e o responsável pela comercialização de suas músicas nessa cidade era Lúcio Teixeira. No entanto, esta relação comercial tornou-se desgastante, a ponto de Valério queixar-se: 'eu faço música, eles vendem e eu ganho uma ninharia', segundo relato de sua neta, Maria Luiza. Quando Valério Vieira se mudou para São Paulo, em 1894, suas músicas estavam mais valorizadas e a edição de suas composições estava a cargo da Casa Levy. Mesmo tendo a fotografia como ocupação principal, nunca abandonou os saraus e nem a música, conti- 
nuando a compor suas valsas, polcas, sendo muito requisitado para tocar para a plateia presente nas reuniões da Casa Levy. Portanto, para reconstituirmos a trajetória de Valério Vieira temos que, obrigatoriamente, cruzar suas produções no campo da música e fotografia." Balady (2012, p. 39-40).

91. Em inglês, há a distinção entre imagemaker e imagetaker, sendo que o primeiro "constrói" suas imagens e o segundo "toma" suas imagens, sem interferir na concepção da cena. Valério Vieira encontra-se claramente na primeira categoria. Além de imagemaker, foi também musicmaker, na medida em que compôs suas próprias músicas.

92. Georges Méliès também realiza um filme a partir do ritmo cakewalk, o que indica sua circulação tanto nos salões brasileiros como nos franceses. Em Le cakewalk infernal (1903), Méliès trabalha intensamente com o plano da dança e da performance. Por meio da trucagem, separa os membros do corpo, no momento em que representa o diabo. Pela irreverência e pela mobilidade corporal, guarda relação direta com a capa da cakewalk "Capoeira", de Valério Vieira.

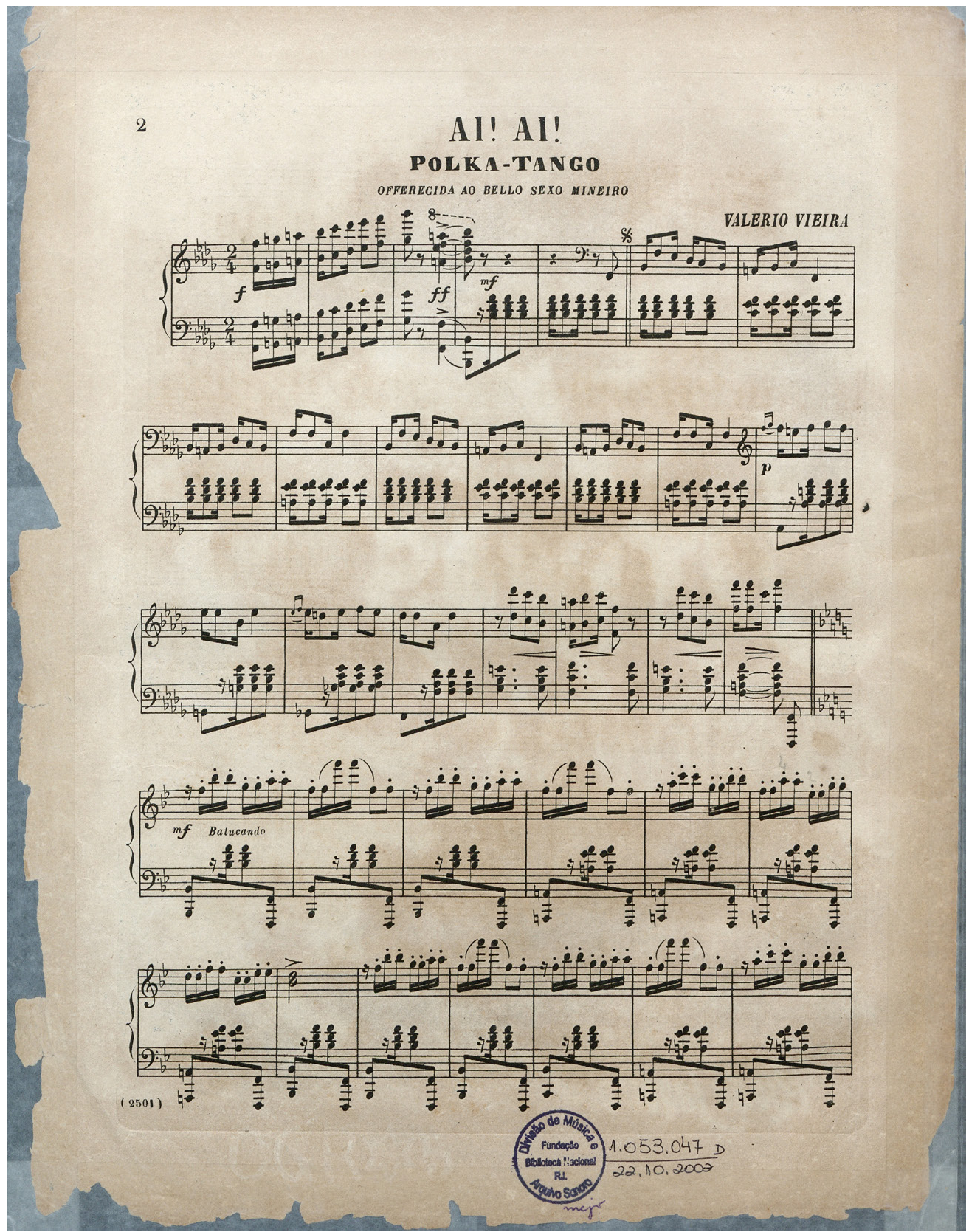

Figura 12 - Partitura de "Ai!Ai!", Polka-Tango (1889), Valério Vieira, "Offerecida ao Bello Sexo Mineiro". Fonte: Acervo Biblioteca Nacional.

Há três partituras de Valério Vieira depositadas no acervo da Biblioteca Nacional, a habanera "La Irenita", feita para sua primeira esposa, Irene, a polca "Catita", dedicada ao "particular amigo Carlos Costa", e a polca-tango "Ai! Ai!", oferecida ao "bello sexo mineiro" (Figura 12). No acervo do Museu Paulista estão 
as valsas "Adamastor" e "As Tuas Lágrimas", as polcas "Paulista" e "Valeriopolka", além de reproduções de "Ai! Ai!", "Catita" e "La Irenita", da valsa "Vivi" e da cakewalk "Capoeira". Há ainda amplo conjunto de partituras de seu filho, Roque Valério Vieira, que reúne maxixes, tangos, fox-trots, fados, ragtimes, duas valsas lentas, uma black-bottom e um "Hymno da Patria Nova", oferecido a Getúlio Vargas em 1930. Segundo Sonia Balady, Valerio teria composto inúmeras músicas, das quais restaram partituras de apenas nove. ${ }^{93}$

Os estilos musicais frequentados por Valerio se inserem em um contexto em que compositores como Ernesto Nazareth (1863-1934) e Chiquinha Gonzaga (1 8471935) trabalharam, um momento de busca por consolidação de ritmos genuinamente "brasileiros" por meio da importação e da subsequente transformação dos padrões importados. A fusão do popular com o erudito deu luz a uma nova matriz musical, na qual os estilos trazidos de fora, como a valsa, a polca, o tango, o fox-trot, o cakewalk ou o ragtime, se misturavam a batidas nacionais em vias de consolidação, como o maxixe, o samba e o choro. ${ }^{94}$ Em suas breves considerações sobre a música de Valerio, Paulo Rydlewski delineia um compositor de obra "despretensiosa e bem humorada".

Não se trata de um compositor inspirado, inovador, porque Valerio teve o bom senso de nunca desejar sê-lo. Ouso dizer que sua música não pretende nada além de entreter, produzir bons momentos musicais onde a sociabilidade, a galanteria e outras qualidades esquecidas pelos homens de hoje em dia possam prevalecer. ${ }^{95}$

Talvez por presente do destino, o grande fotógrafo e despretensioso músico Valério Vieira teve uma de suas partituras resgatadas cerca de dez anos após sua morte. Foi no dia 27 de março de 1952, diante de uma plateia que lotava o auditório da Rádio Tupi no Rio de Janeiro para acompanhar, ao vivo, a transmissão do programa $\bigcirc$ Pessoal da Velha Guarda. O resgate foi realizado por Almirante (1908-1980), produtor artístico do programa, e a nova versão foi tarefa dada a ninguém menos que Pixinguinha (1897-1973), que liderava a "orquestra". 96 Sonia Balady localizou uma carta endereçada a Almirante que talvez possa estar na origem da escolha da música de Valerio. Escrita por Alfredo Nunes, à época presidente do Sindicado dos Músicos na capital federal, foi endereçada no dia 18 de fevereiro de 1949. $\bigcirc$ missivista resgata uma importante passagem na carreira de Valerio, enviando juntamente com a carta um fragmento do jornal "Diário de Notícias", de 1889, no qual se encontra a partitura da polka-tango "Ai!Ai", que "fez grande sucesso àquela época". Além de relatar a breve "carreira" de Valerio como músico, no período em que morou no Rio de Janeiro, esboça uma história obviamente fictícia sobre seu paradeiro, talvez imaginada ou chegada aos seus ouvidos por meio de boatos.
93. "Para Valério, música e fotografia se complementavam. Compôs inúmeras músicas, a maioria com títulos relacionados à fotografia, como Photográfica, Photovalsa e Retratista. [...] Valério Vieira era uma pessoa refinada, segundo depoimento de seus contemporâneos: sua gentileza e polidez também são notadas em pequenos gestos como o de dedicar cada composição a alguém ou a um grupo específico. A valsa Adamastor foi 'dedicada à officialidade', enquanto que a As tuas lágrimas, à sua esposa $\mathrm{Au}$ gusta Carmem; a polca-tango Ai! Ai! oferecida ao belo sexo mineiro, a Valériopolka à imprensa paulista, Paulista ao 'bello sexo Taubatense' e Catita dedicada a seu amigo Carlos Costa; a habanera La Irenita a Exma. Snra D. Irene M. de Moura (mais tarde veio a ser sua esposa), e a cake walk "Capoeira", ao amigo e irmão, Pedro Vieira. Segundo depoimento de familiares, nesse meio social que frequentava, Valério conheceu a jovem Irene Maria de Moura, com quem veio a se casar. Mas o casamento teve breve duração, pois Irene faleceu em 1886." Balady (2012, p. 36-38).

94. "Nessa época, salões para bailes públicos e as chamadas tea rooms se espalhavam pelas cidades. A música popular era vibrante, entusiástica e, quase sempre, permitia o improviso. Notas e ritmos sincopados se tornaram tão populares com o público que os editores de partituras incluíram a palavra 'sincopado' em seus anúncios. Em 'saraus' em livrarias, confeitarias, bailes de formatura, festas familiares, e mesmo festas não tão familiares em cortiços e bordéis, a grande mistura de ritmos acontecia. Surge o 'tango brasileiro' de Ernesto Nazareth, que não era nada além de um maxixe com o nome modificado, surge o 
Samba em 1917 e as portas da originalidade definitivamente se abrem para o nascimento da música verdadeiramente brasileira." Paulo Rydlewski citado por Balady (2012, p. 189).

95. Ibid. (p. 190).

96 Sobre atuação de Almirante (Henrique Foreis Domingues) (1908-1980) como radialista e produtor de programas radiofônicos, cf. pesquisa de Anna Paes, intitulada "Almirante e O Pessoal da Velha Guarda: memória, história e identidade". Sobre Almirante, Paes afirma: "Sua trajetória foi marcada pelo pioneirismo na sistematização de fontes sobre a música popular urbana e por ações de defesa e valorização do patrimônio cultural e artístico brasileiro. Um dos exemplos emblemáticos dessa linha de ação se evidencia no programa de rádio semanal 'O Pessoal da Velha Guarda', apresentado e produzido por Almirante entre 1947 e 1952 , sob a direção musical de Pixinguinha, levando ao público interpretações ao vivo de músicas tradicionais das serenatas do Rio Antigo - polcas, schottischs, valsas, modinhas, choros - de fins do século XIX e início do XX.” Paes (2012, p. viii).

97. Alfredo Nunes, em carta endereçada a Almirante, 18/02/1949. Acervo sob guarda do Instituto Moreira Salles). Cf. Balady (2012, p. 35).

98. Almirante, narrado no programa "O Pessoal da Velha Guarda" n. 19, transmitido ao vivo no dia 27 mar. 1952.
Valério, foi ótimo pianista e compositor - que como todos de sua época - dotado de excessiva modéstia não tinha a menor vaidade de artista e éra solicitado em todos os salões, não só como intérprete de sua musica, como ainda pelos seus demais predicados morais e intelectuais.

Foi funcionário público, bacharel e morreu moço. ${ }^{97}$

Tudo indica que Valério Vieira não teve proeminência no cenário musical paulista do início do século XX, dedicando-se plenamente à fotografia como atividade profissional após se estabelecer na capital do estado. O reconhecimento de seus dotes musicais parece restrito aos salões cariocas nas duas últimas décadas do século XIX. Mas Almirante nos aporta outro indício de que as músicas de Valerio podem ter circulado para além desse contexto. Ao apresentar "Ai!Ai!" ao público, antes de ser executada, Almirante não faz menção à carta de Alfredo Nunes, mas a outra correspondência, enviada por ouvinte da cidade de Campanha, no sul de Minas Gerais. Sabe-se que Valerio atuou no Vale do Paraíba. Teriam suas músicas atravessado a Serra do Mar, em direção a paragens mineiras? Parte de sua carreira se desenrolou em Ouro Preto (MG), já bastante distante geograficamente de Campanha. Escutemos as palavras pronunciadas pelo radialista.

Este programa, pelo que podemos verificar por nossa correspondência, é muito ouvido em Minas Gerais. Há ali nas Minas Gerais ouvintes atentos a essas audições. Naturalmente há de ser pra eles uma alegria maior sempre que exibimos aqui melodias de seus conterrâneos. Minas Gerais na verdade está muito bem representada na Velha Guarda. E como boa prova disso, aqui vai para os mineiros e em atenção especial ao pedido de Dona Honorina dos Passos Miranda, da cidade de Campanha, no sul de Minas, uma delicada polca que o compositor mineiro Valério Vieira dedicou às moças de sua terra. A música tem um tom de um suspiro de amor. E para the acrescentar tal intenção, Valério Vieira numa pausa introduziu um suspiro falado, um "Ai, ai". Um "Ai, ai" sentido, que foi servir também para dar nome à sua música. Atenção, pois, ouvintes da Velha Guarda e suspirem conosco durante este lindo arranjo de Pixinguinha para a polca "Ai!, Ai!" de Valério Vieira. ${ }^{98}$

Podemos nos lançar a conjectura, verossímil, de que Almirante tenha criado a personagem Honorina dos Passos Miranda, inventando, de quebra, as origens mineiras de Valerio, que nasceu em Angra dos Reis (RJ). Caso não tenha cometido tal disparate, resta-nos imaginar como a polka-tango de Valerio teria chegado aos ouvidos de dona Honorina, que, por sua vez, em um dia qualquer de 1949, demandou a música a Almirante, fazendo eco à carta de Alfredo Nunes, que narrara brevemente as aventuras do músico nos salões cariocas do fin de siècle. Almirante transmite a tarefa de reapreciação da música a Pixinguinha, que a 
transporta ao formato orquestrado em série de partituras manuscritas datadas de 6 de junho de 1949. Mas sua execução só se daria quase três anos depois.

$\bigcirc$ programa $\bigcirc$ Pessoal da Velha Guarda foi criado com a proposta de resgatar músicas de compositores antigos, que teriam ajudado a forjar, na visão de Almirante, o que seria uma autêntica música popular nacional. ${ }^{99}$ Ao longo de todos os programas, em que retoma composições de artistas famosos e outros nem tanto, relembra anedotas e histórias, Almirante não deixa nunca de realçar a "brasilidade", das "coisas de nossa terra, da nossa gente", diante de uma indústria do entretenimento cada vez mais globalizada e ligada aos meios de comunicação de massa, dentre os quais o rádio tinha enorme relevância à época. ${ }^{100}$ Um dos principais vetores dessa reapreciação do repertório que funda a moderna música popular brasileira é Pixinguinha, que transpõe as músicas recolhidas por Almirante ou sugeridas pelo público ouvinte ao longo das audições para o formato orquestral do grupo que dirige, no qual implementa uma série de inovações, dentre elas o uso intenso da percussão aliado a instrumentos de base do choro e das orquestras populares. "Essa configuração de base rítmico-harmônica passaria a ser o emblema de uma era na música popular brasileira" ${ }^{101}$ A releitura de Pixinguinha, portanto, traz novas cores à partitura original de Valério Vieira, incorporando a levada da percussão em sua sonoridade, como demonstra o emprego recorrente da indicação "batucada", em suas partituras manuscritas. Pixinguinha parece "sanar" a falta de instrumentos de percussão em Os trinta Valérios, incorporando o ritmo do samba na melodia da música (Figura 13).

A execução de "Ai! Ai!" pela orquestra do Pessoal da Velha Guarda faz ressoar Os trinta Valérios. Ela sem dúvida reverbera o ambiente descontraído em que o artista apresenta seu espetáculo, sua peça fotomusical. $\bigcirc$ único registro filmado que nos restou das apresentações do grupo liderado por Pixinguinha é de Thomaz Farkas, realizado dia 25 de abril de 1954, no Parque do Ibirapuera, durante as comemorações do IV Centenário da Cidade de São Paulo. ${ }^{102}$ Evento de grande envergadura simbólica para a consolidação da imagem paulista no imaginário da modernidade brasileira, foi coincidentemente o palco da apresentação de Pixinguinha e seus "bambas". O elemento que logo chama atenção justo por sua descontração é o fato de que os músicos dançam enquanto tocam. Executar a música é movimento que se irradia das mãos, em sua relação com o instrumento, para o todo o corpo. Tocar é entrar em transe coletivo, durante o qual prazer e concentração se fundem e se confundem. Nada contra os músicos sérios e compenetrados demais. Essa malemolência é um jeito de corpo presente tanto em Valerio como em Pixinguinha, uma ressonância que se faz sentir ao longo de parte significativa da produção artística brasileira. Sente-se um princípio de positividade no remelexo, que toca certa brasilidade.
99. No programa de número 10 , transmitido no dia 3 de março de 1948, Almirante explicita a proposta. "Boa noite, ouvintes de todo o Brasil! Boa noite amigos incondicionais da Velha Guarda, o que equivale a dizer amigos incondicionais das nossas coisas, da nossa terra, da nossa gente. No início de mais esta audição brasileiríssima, quero dizer uma rápida palavra sobre as declarações do grande patrício maestro Villa-Lobos em Londres. Numa recepção em que foi o convidado de honra, Villa-Lobos falou do seu grande sonho: a pacificação do mundo por intermédio da música. Seria de fato uma realização grandiosa. [...] A grande pacificação poderia ser feita de maneira que todos os povos identificassem os demais pelas suas canções, pelas suas músicas nativas. Nesse caso, cada país deveria se empenhar para que bom número de suas canções atravessasse todas as fronteiras, levando-os a outros povos a certeza de sua existência, e o meio de reconhecer suas criaturas. Mas tais músicas deveriam ter penetração nas massas, e para isso, ouvintes, só mesmo a música popular. Envidemos, pois, esforços desde já, para que nossas músicas sejam conhecidas em todo o mundo, e um dia, quando um viajante brasileiro chegar aos mais longínquos países, não precisará dizer de boca, com palavras, a sua nacionalidade, bastará assobiar ou cantarolar uns poucos compassos de o 'Tico-Tico no Fubá', ou do 'Carinhoso', ou do 'Copacabana', e todos saberão que ali está um patrício nosso." (Almirante, narrado no programa $O$ Pessoal da Velha Guarda n. 10, 03 mar. 1948).

100. Foi a publicidade veiculada que permitiu a Almirante manter seu programa no ar durante tanto tempo, 
empregando diversos músicos, em apresentações ao vivo. O rádio se massificava nos ambientes urbanos do Brasil no final da década de 1940 , o que pode ser deduzido também da intensa participação dos ouvintes nas músicas selecionadas. Dentre os patrocinadores do programa estiveram Sal de Fruta Eno, Vinhos Único e Emulsão Scotch.

101. "Para obter esse resultado, Pixinguinha recorreu a percussionistas ligados ao Estácio e à Cidade Nova, que traziam seus instrumentos recém-criados, até então nunca utilizados em estúdios de gravação. Com isso, consolidou-se o casamento entre essas novas cores da percussão e os instrumentos de base vindos do choro (violões e cavaquinho) e das orquestras populares (piano e contrabaixo)." Aragão (2010, p. 29)

102. Detalhes sobre essa filmagem histórica estão no filme Pixinguinha e a Velba Guarda do Samba (2007), de Thomaz Farkas e Ricardo Dias.

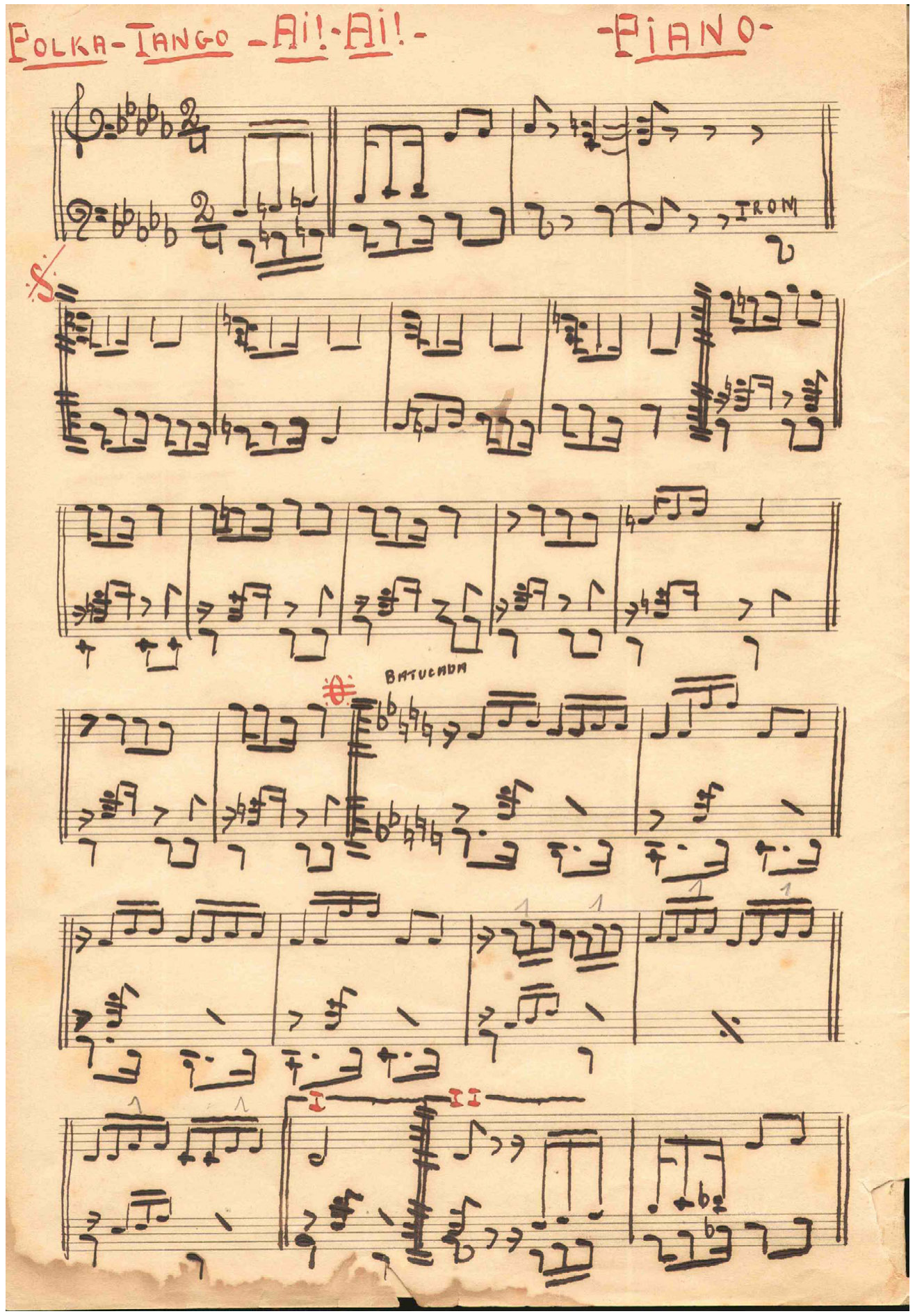

Figura 13 - Partitura de piano de "Ai! Ai!" polca-tango de Valério Vieira, arranjo de Pixinguinha 06/06/1949 (primeira página da parte de piano). Acervo Pixinguinha / Instituto Moreira Salles. 
Em 2010, o Instituto Moreira Salles promoveu a edição de uma série de 36 partituras de Pixinguinha produzidas para O Pessoal da Velha Guarda. "Ai!Ai!" foi escolhida para figurar na publicação, que é acompanhada de um pequeno livreto com artigos sobre o programa e as peculiaridades do trabalho de Pixinguinha. Anna Paes, estudiosa da música que assina a biografia dos presentes, não cruzou os dados biográficos do célebre fotógrafo criador de Os trinta Valérios. Seu nome se encontra junto ao de outros personagens "anônimos" da música popular brasileira, nos escombros que se interpõem entre nosso tempo e a cena musical carioca no final século XIX. ${ }^{103}$ Célebre fotógrafo, músico incógnito. ${ }^{104}$

\section{CONCLUSÃO: UM MESTRE NA PERIFERIA DO CAPITALISMO}

Vimos ao longo do artigo como Valério Vieira assume uma série de papéis ao encarnar a figura de Valerio, forma através da qual se apresentava à distinta clientela. Os trinta Valérios (c. 1901) é uma obra de extrema originalidade, ao propor uma mescla de três artifícios que posicionam a fotografia plenamente no polo da manipulação e da ficção: a mise-en-scène, o autorretrato e a fotomontagem. Ao assumir-se como autor e como ator, como fotógrafo e como fotografado, como diretor e montador, ao criar uma peça que dialoga com aspectos do teatro, do cinema e da música, Valerio ganha uma dimensão única no contexto da então incipiente da modernidade brasileira. Pretendemos ter coberto as múltiplas determinações dessa obra extremamente original, surgida ainda na passagem do século XIX ao século XX.

Por outro lado, a análise do processo de criação do Segundo panorama de São Paulo, realizado em 1922, nos permitiu desdobrar ainda outra faceta de Valerio, através da qual ele se assume como um artista ligado às pretensões oficiais de propaganda governamental. Para exprimir o gigantismo da metrópole que nascia, ele desenvolveu um complexo e ardoroso trabalho, baseado na captação e fusão de fotografias em uma única imagem panorâmica da cidade de São Paulo, que media 16 metros de cumprimento por 2 metros de altura, um recorde mundial para sua época. Ainda que tenha sido concebida a partir do agenciamento de diferentes tomadas, a imagem panorâmica de Valerio preza pela coesão e o realismo e busca passar a sensação de um progresso ordenado, obtendo um efeito bastante distinto daquele obtido em Os trinta Valérios.

Os desdobramentos realizados a partir de correlações entre a obra de Valerio e os campos do cinema, do teatro e da música nos permitem vislumbrar a figura de um criador múltiplo e plenamente conectado às preocupações de seu tempo. A
103. "Não foram encontradas informações biográficas sobre alguns dos compositores. Pouco ou nada se sabe sobre a vida de Amadeu Taborda, Aristóteles de Magalhães Pery, Balduíno Rodrigues do Nascimento, Cesare Bonafous, Eduardinho Violão, Passos, Bornéo e Bernabé, Valério Vieira e Zeferino M. Hourcades." Paes (2010, p. 59).

104. Por uma ironia do destino, o Valério Vieira músico foi resgatado antes do Valério Vieira fotógrafo. A apresentação de "Ai!Ai!" no auditório da Rádio Tupi se deu onze anos após sua morte, enquanto que "Os Trinta Valerios" e o "Segundo Panorama de São Paulo” só seriam resgatadas por Pietro Maria Bardi em 1972, para a exposição dos 50 anos da Semana de Arte Moderna. Seguiram-se a isso artigos de Boris Kossoy na imprensa e em revistas especializadas, na década de 1970 , e algumas linhas dedicadas a ele em sua obra "Origens e Expansão da Fotografia no Brasil" (Kossoy, 1980), além de menção realizada por Gilberto Ferrez e Weston Naef no livro Pioneer photographers of Brazil. Ferrez; Naef (1976). 
105. Boris Kossoy também aponta para a excepcionalidade da obra de Valério Vieira, como indica artigo publicado por ele sobre o fotógrafo em $O$ Estado de $S$. Paulo, dia 4 de março de 1973: "Valério Vieira: viveu em São Paulo um dos gênios da fotografia mundial". gravação, em 1952, de uma de suas composições musicais por Pixinguinha e a orquestra do programa $O$ Pessoal da Velha Guarda, dirigido por Almirante, atesta que, também do ponto de vista musical, existem aspectos notáveis em sua criação. Ainda há muito para se descobrir e se discutir sobre a vida e principalmente sobre a obra de Valério Vieira. Grande parte de sua trajetória permanece um mistério. Não temos pistas de como foi concebida Os trinta Valérios, pouco sabemos acerca de outros experimentos no campo da fotomontagem, quase não restam depoimentos do próprio personagem. Sua volumosa produção de retratos está dispersa nas mãos de colecionadores particulares. Há pouca coisa em coleções públicas, mas o que temos até aqui afigura o panorama de um notável fotógrafo-artista, autor-ator, músico, personagem e personalidade múltipla, autêntico e irrequieto mestre que bailou e brilhou em aristocráticos salões da periferia do planeta. ${ }^{105}$ 


\section{REFERÊNCIAS}

LIVROS, ARTIGOS E TESES

ALTAFINI, Thiago. Cinema documentário brasileiro: evolução histórica da linguagem. Biblioteca Online de Ciências da Comunicação: <https://bit.ly/2Kw9V1v, 1999>.

AMARAL, Aracy. Artes plásticas na Semana de 22. São Paulo: Editora 34, 1998.

ANSÓN, Antonio. El limpiabotas de daguerre. Murcia: Puertas de Castilla, 2007.

ARAGÃO, Paulo. As cores novas do arranjador. In: LEME, Bia Paes (org.). Pixinguinha na pauta. Rio de Janeiro: Instituto Moreira Salles, 2010.

ARAÚJO, Íris Morais. Militão Augusto de Azevedo: fotografia, história e antropologia. São Paulo: Alameda, 2010.

BALADY, Sonia U. Valério Vieira: um dos pioneiros da experimentação fotográfica no Brasil. São Paulo: Universidade de São Paulo, 2012.

BARBUY, Heloísa. A cidade-exposição: comércio e cosmopolitismo em São Paulo, 1860-1914. São Paulo: Edusp, 2006.

BARBUY, Heloísa; FERNANDES JR., R.; FREHSE, F. Militão Augusto de Azevedo. São Paulo: CosacNaify, 2012.

BARDI, Pietro Maria. O Modernismo no Brasil. São Paulo: Banco Sudameris do Brasil, 1978.

BARDI, Pietro Maria. Em torno da fotografia no brasil. São Paulo: Banco Sudameris do Brasil, 1986.

BARTHES, Roland. A câmara clara. Rio de Janeiro: Editora Nova Fronteira, 1980.

BATCHEN, Geoffrey. Burning with Desire. Cambridge: The MIT Press, 1999.

BAYARD, Hippolyte. Hippolyte Bayard: Photo Poche 91. Arles: Actes Sud, 2001. 
BAZOU, Sébastien. Texto de apresentação do DVD Méliès, le cinémagicien. Paris: Arte Video, 2001.

BELLOUR, Raymond. Les hommes, le dimanche. Crisnée: Yelow Now, 2009.

BELTRAMIM, Fabiana M. S. Entre o estúdio e a rua: a trajetória de Vincenzo Pastore, fotógrafo do cotidiano. São Paulo: USP-FFLCH, 2015.

BENJAMIN, Walter. Obras escolbidas 1: magia e técnica, arte e política. São Paulo: Brasiliense, 1986.

BENJAMIN, Walter. The arcades project. Cambridge: The MIT Press, 1999.

CAMARGO, Mônica, MENDES, Ricardo. Fotografia: cultura e fotografia paulista no século XX. São Paulo: Secretaria Municipal de Cultura, 1992.

CARADEC, F., NOHAIN, J. Fregoli: sa vie et ses secrets. Paris: Jeune Parque, 1968.

CARADEC, F., NOHAIN, J. Le grand troc des trucs. De quelques interactions entre prestidigitation, photographie et cinématographie. In: GUIDO, L.; LUGON, O. Fixe / Animé : croisements de la photographie et du cinéma au XXe siècle. Lausanne: L'Age D’Homme, 2010.

CARADEC, F.; NOHAIN, J. Avant l'avant-garde: du jeu en photographie 1890-1940. Paris: Textuel, 2015.

CHIK, Caroline. Méliès, photographie et arrêt de caméra. In: GAUDREAULT, A.; LE FORESTIER, L. (orgs.). Méliès carrefour des attractions. Rennes: Les Presses Universitaires de Rennes, 2014.

COURSODON, Jean-Pierre. Buster Keaton. Paris: Seghers, 1973.

COVAS, Eduardo Alves. O olhar fotográfico de Francisco Brandão. Campinas: Instituto de Artes, Unicamp, 2009.

DELEUZE, Gilles. A imagem-movimento. São Paulo: Brasiliense, 1985.

DIETRICH, Ana Maria (org.). Gaensly no acervo da Light, 1899-1925. São Paulo: BPR Publishers, 2001.

DREUX, Emmanuel. Le cinéma burlesque ou la subversion par le geste. Paris: l'Harmattan, 2007. 
FABRIS, Annateresa (org.). Fotografia: usos e funções no século XIX. São Paulo: Edusp, 1991.

FAORO, Raimundo. Os donos do poder. São Paulo: Globo, 2001.

FERNANDES JR., Rubens. Fotografia no Brasil e modernidade. In: SCHWARTZ, J. (org.). Brasil, 1920-1950: da antropofagia a Brasília. São Paulo: CosacNaify, 2002.

FERNANDES JR., Rubens. Aurélio Becherini: lições e demolições do olhar. Natal: XXXI Congresso de Ciências da Comunicação, 2008.

FERNANDES JR., R.; KOSSOY, B.; SEGAWA, H.; SIQUEIRA, H. Guilherme Gaensly. São Paulo: CosacNaify, 2011.

FERREZ, G.; NAEF, W. Pioneer photographers of Brazil: 1840-1920. Nova York: The Center for Inter-American Relations, 1976.

FREUND, Gisèle. Photography \& society. Boston: David R. Godine, 1980.

GAUDREAULT, André. Cinéma et attraction: pour une nouvelle histoire du cinématographe. Paris: CNRS Éditions, 2008.

GAUDREAULT, André. La cinématographie-attraction chez Méliès. In: GAUDREAULT, A.; LE FORESTIER, L. (orgs.). Méliès carrefour des attractions. Rennes: Presses Universitaires de Rennes, 2014.

GOULART, Paulo Cezar.; MENDES, Ricardo. Noticiario geral da photographia paulistana: 1839-1900. São Paulo: Centro Cultural São Paulo, 2011.

GRANJEIRO, Cândido D. As artes de um negócio: a febre photographica - São Paulo, 18621886. São Paulo: Fapesp, 2000.

JANOVITCH, Paula Ester. Preso por trocadilbo: a imprensa de narrativa irreverente paulistana de 1900 a 1911. São Paulo: Alameda, 2006.

KOSSOY, Boris. Origens e expansão da fotografia no Brasil: século XIX. Rio de Janeiro: Funarte, 1980.

KOSSOY, Boris. São Paulo, 1900. São Paulo: Livraria Kosmos, 1988. 
KOSSOY, Boris. Realidades e ficções na trama fotográfica. São Paulo: Ateliê Editorial, 1999.

KOSSOY, Boris. Fotografia E História. São Paulo: Ateliê Editorial, 2001.

KOSSOY, Boris. Dicionário bistórico-fotográfico brasileiro: fotógrafos e ofício da fotografia no Brasil (1833-1910). São Paulo: Instituto Moreira Salles, 2002.

KOSSOY, Boris. Os tempos da fotografia: o efêmero e o perpétuo. São Paulo: Ateliê Editorial, 2007.

KRACAUER, Siegfried. From Caligari to Hitler: a psychological history of the german film. Princeton: Princeton University Press, 2004.

KRÀL, Petr. Le burlesque ou la morale de la tarte à la crème. Paris: Ramsay, 2007.

LAGO, Pedro Corrêa. Militão Augusto de Azevedo: São Paulo nos anos 1860. Rio de Janeiro: Capivara, 2001.

LISTA, Giovanni. Cinéma et photographie futuristes. Paris: Skira, 2008.

MADIO, Teresa. A fotografia na imprensa diária paulistana nas primeiras décadas do século XX: O Estado de S. Paulo. História, São Paulo, v. 26, n. 2, p. 61-91, 2007.

MALTHÊTE, J.; MANNONI, L. Méliès: magie et cinéma. Paris: Cinémathèque Française, 2008.

MCLAREN, Norman. Texto incluído no DVD Georges Méliès: Le premier magicien du cinéma. Paris: Lobster Films, 2008.

MENDES, Ricardo. Once Upon a Time: uma história da História da Fotografia brasileira. Anais do Museu Paulista, São Paulo, v. 6/7, p. 183-205, 2003.

MENDES, Ricardo. "O Valério comprimenta-vos": persona e invenção na virada do século. São Paulo: 2006. Disponível em: <https://bit.ly/38nlUqa>.

MONGIN, Olivier. Buster Keaton: L'étoile filante. Paris: Hachette, 1995.

OLIVEIRA, Diogo da Costa. Almirante e o pessoal da velha guarda: memória, história e identidade. Rio de Janeiro: Unirio, 2012. 
PETRONE, Pasquale. A cidade de São Paulo no século XX. Revista de História, São Paulo, v. 10, n. 21-22, p. 136-139, 1955.

RODRIGUEZ, Teraiza. Síndrome de Fregoli: a propósito de un caso. Alcmeon, Buenos Aires, a. XVII, v. 14, n. 4, junio de 2008.

SCHEFER, Jean-Louis. Images mobiles : récits, visages, flocons. Paris: P.O.L., 2009.

STRAUVEN, Wanda. The cinema of attractions reloaded. Amsterdã: Amsterdam University Press, 2006.

SÜSSEKIND, Flora. Cinematógrafo de letras. São Paulo: Cia. das Letras, 1987.

TALBOT, Henry Fox. The Pencil of Nature. Londres: 1844. Versão digital estabelecida em 2010. Disponível em: <https://bit.ly/3hcyqNq>.

THARRATS, Juan-Gabriel. Segundo de Chomón: un pionnier méconnu du cinéma européen. Paris: L'Harmattan, 2009.

TURAZZI, Maria Inez. A Vontade Panorâmica. In: INSTITUTO MOREIRA SALLES. O Brasil de Marc Ferrez. São Paulo: IMS, 2005.

VELlOSO, Mônica Pimenta. Modernismo no Rio de Janeiro. Petrópolis: KBR, 2015.

VIMENET, Pascal. Émile Cohl. Montreuil: Ed. de l'Oeil, 2008.

WEISS, Peter. Le Cinéma d'Avant-Garde. Paris: L'Arche, 1989.

Artigo apresentado em: 20/5/2020. Aprovado em 9/10/2020.

\section{(cc) BY}

